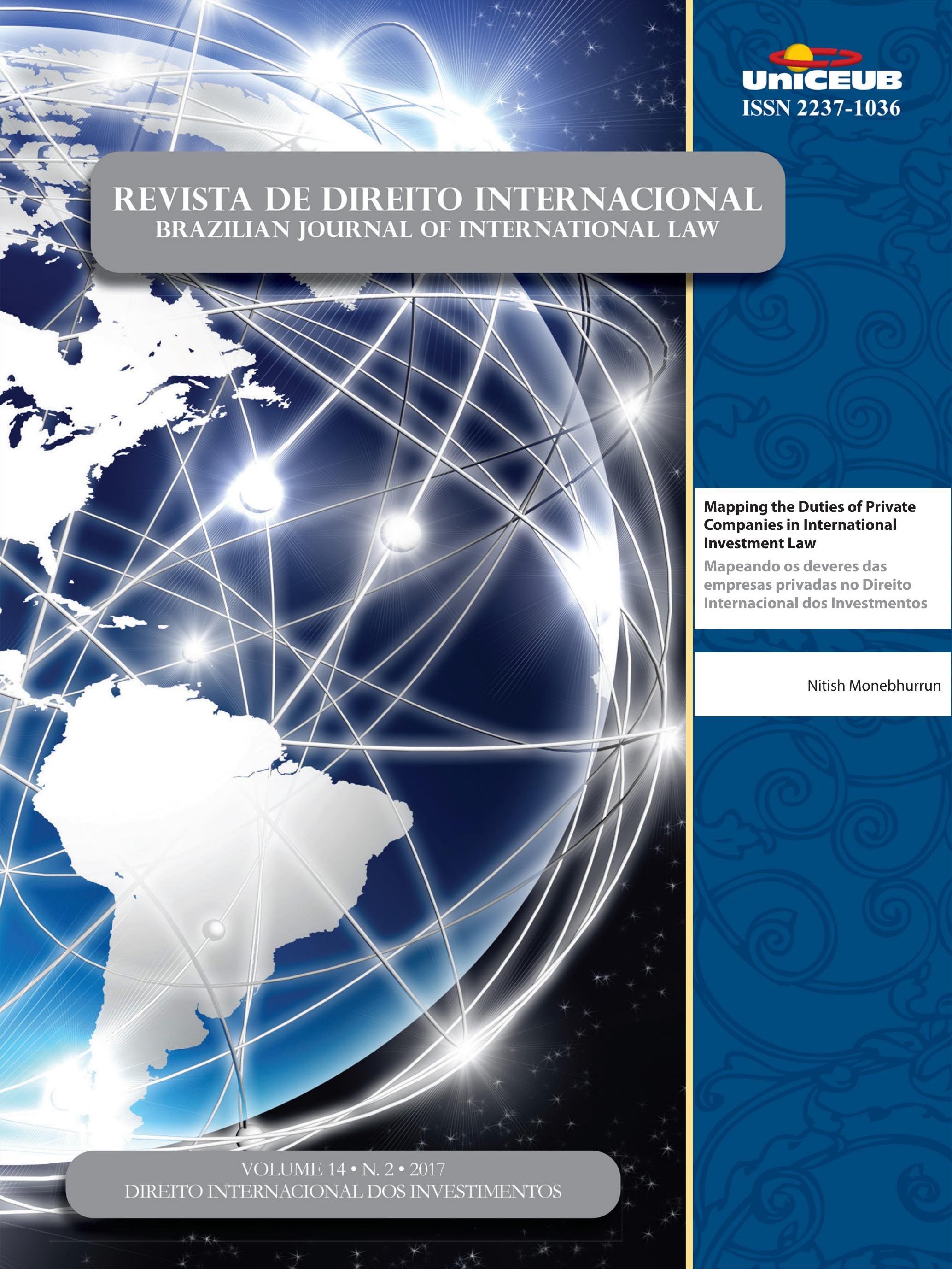




\section{Sumário}

I. Crônicas do Direito Internacional ...............................................1

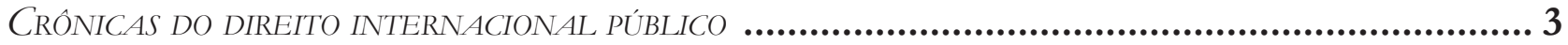

A resolução 2272 (2016) do Conselho de Segurança das Nações Unidas - O POSICIONAMENTO DA ONU FACE ÀS ALEGAÇÕES DE ABUSO E EXPLORAÇÃo SEXUAL POR SUAS

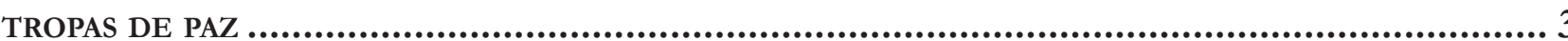

Sarah Dayanna Lacerda Martins Lima

CRÓNICAS DE DiREITo INTERNACIONAL PRIVADO...................................................................

Nadia de Araujo, Marcelo De Nardi, Gustavo Ribeiro, Fabrício Polido e Inez Lopes

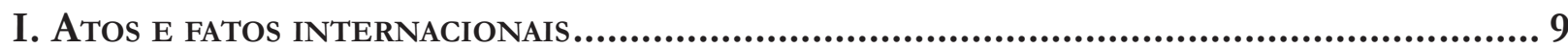

Crônica 1. Novidades de 2017 SObRE CIRCulaÇÃo faCilitada DE SENTENÇAS ESTRANGEIRAS 9

Crônica 2: O Direito Transnacional e os episódios das Carnes.........................................16

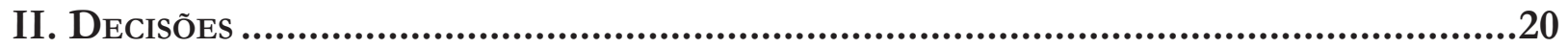

Crônica 3: A Irresistível ForÇa da ORDEM PÚblica E A HOMOLOGaÇÃo DE SENTENÇAS

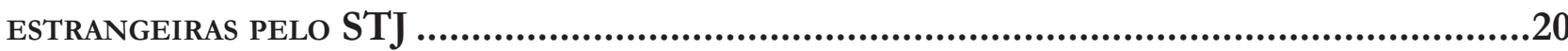

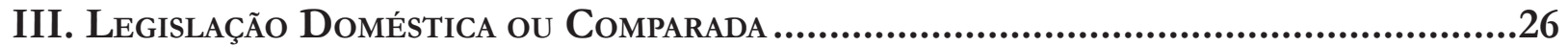

Crônica 4 - Dignidade da pessoa humana e mudança de paradigma da Lei de Migração

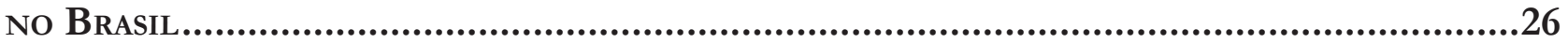

II. Dossiê especial: Direito Internacional dos InVEstimentos ................35

Non-adjudicatory State-State Mechanisms in Investment Dispute Prevention and Dispute Settlement: Joint Interpretations, Filters and Focal Points 
Mapping the Duties of Private Companies in International Investment Law .50 Nitish Monebhurrun

LA LÉGALITÉ DE L'INVESTISSEMENT DEVANT L'ARBITRE INTERNATIONAL: À LA RECHERCHE D'UN POINT D'ÉQUILIBRE .73 Hervé Ascensio

Host STATES AND STATE-STATE INVESTMENT ARBITRATION: STRATEGIES AND CHALlENGES......81 Murilo Otávio Lubamdo de Melo

Right to Regulate, Margin of Appreciation and Proportionality: Current Status in Investment Arbitration in Light of Philip Morris V. Uruguay. .95 Giovanni Zarra

Investments on Disputed Territory: Indispensable Parties and Indispensable Issues....122 Peter Tzeng

The Influence of General Exceptions on the Interpretation of National

Treatment in INTERNATIONAL INVESTMENT LAW. 140 Louis-Marie Chauvel

UMA PRoposta de REFleXão SObRe os ACFIs: Até QUE PONTO O TRATAMENTo de NAÇão MAIS FAVORECIDA PODE MINAR A ESTRATÉGIA POLÍTICA QUE OS EMBASA? 160

Michelle Ratton Sanchez Badin, Daniel Tavela Luis e Mario Alfredo de Oliveira

ECUADOR's 2017 TERMINATION OF TREATIES: HOW NOT TO EXIT THE INTERNATIONAL INVESTMENT REGIME 179

Jose Gustavo Prieto Muñoz

ONE BELT, ONE ROAD: NOVAS INTERFACES ENTRE O COMÉRCIO E OS INVESTIMENTOS INTERNACIONAIS 193

Flávio Marcelo Rodrigues Bruno e Marilda Rosado de Sá Ribeiro

III. Artigos Sobre outros TEMAS..................................................... 214

TolerânCIA E REFugIO: UM ENSAIO A PARTIR Do ACORdo EU-TurQUiA 216 Flávia Cristina Piovesan e Ana Carolina Lopes Olsen 
O TRATAMENTO do APÁtridA NA NOVA LEI DE MIGRAÇÃo: ENTRE AVANÇOS E RETROCESSOS...237 Jahyr-Philippe Bichara

O caráter humanista da Lei de Migrações: aVAnços da Lei N. 13.445/2017 E Os desafios DA REGULAMENTAÇÃO. 254 Marcelo Dias Varella, Clarice G. Oliveira, Mariana S.C. Oliveira e Adriana P. Ligiero

Reform of the United Nations Security Council: The Emperor Has No Clothes.268 Ljubo Runjic

A IDEIA DE QUe os LATINO-AMERICANOS PREFEREM O AUTORITARISMO À DEMOCRACIA À luz da reinterpretação dos Critérios do Programa das Nações Unidas para o DesenVolvimento 286

Gina Marcilio Pompeu e Ana Araújo Ximenes Teixeira

A PRoteção da ORIENTAÇÃo SEXUAL E IDENTIDAdE DE GÊNERO DIVERSAS NA CORTE PENAL internacional: Entre Realpolitiks E Os Direitos Humanos

Gustavo Bussmann Ferreira

A desnacionalização e as violações de direitos humanos na República Dominicana. 331 Daniela Menengoti Gonçalves Ribeiro e Rodrigo Ichikawa Claro Silva

CompetênCia do TPI no Caso do ATAque ao hospital de Kunduz: uma análise ENVOLVENDO A JURISDiÇÃo do TPI EM RELAÇÃO A NACIONAIS DE EsTAdOS NÃO-PARTE do Estatuto DE Roma

Filipe Augusto Silva e Renata Mantovani de Lima

A CRIMINALIZAÇÃo DOS IMIGRANTES EM SITUAÇÃo IRREGULAR NA ITÁliA: BIOPOLÍtica E DIREITO PENAL DO AUTOR.

Maiquel Angelo Dezordi Wermuth e Jeannine Tonetto de Aguiar

The New Rules On Trade And Environment Linkage In Preferential Trade Agreements

Alberto do Amaral Júnior e Alebe Linhares Mesquita

Beyond THE Border between the North and the South: towards a Decolonization of EPISTEMOLOGIES AND FIELDS OF RESEARCH ON MERCOSUR 
A aplicabilidade da Convenção de Montreal no direito brasileiro.

Aziz Tuffi Saliba e Alexandre Rodrigues de Souza

REgIME DE TRANSPARÊNCIA FISCAL NA TRIBUTAÇÃo DOS LUCROS AUFERIDOS NO EXTERIOR (CFC RULES): LACUNAS E CONFLITOS NO DIREITO BRASILEIRO

Paulo Rosenblatt e Rodrigo Torres Pimenta Cabral

As Regras Brasileiras de Tributação de Controladas e Coligadas no Exterior: verdadeiras Controlled Foreign Company (CFC) Rules? .......................................465

Melina de Souza Rocha Lukic e Amanda Almeida Muniz

O RETORNO DE BENS CULTURAIS

Aziz Saliba e Alice Lopes Fabris

Direitos culturais e Nações Unidas: uma análise a partir da Declaração Sobre a eliminação de Todas as Formas de Intolerância e Discriminação Baseadas na Religião OU NA CRENÇA

Leilane Serratine Grubba e Márcio Ricardo Staffen

OS REFLEXOS DA PROTEÇÃO INTERNACIONAL DA PROPRIEDADE INTELECTUAL PARA O DESENVOLVIMENTO INTERNO: UMA ANÁLISE SOBRE O SISTEMA PATENTÁRIO BRASILEIRO E A TRANSFERÊNCIA DE TECNOLOGIA

Michele M. Segala e Isabel Christine S. De Gregori

O CASO HIPOTÉTICO DA MORTE DO EMBAIXADOR FRANCÊS NA ESPANHA: DUAS ESPÉCIES DE IUS gentium em Francisco de Vitoria

Rafael Zelesco Barretto

De volta À BeVilaqua: anÁlise ECONÔMICA dA APLICAÇão do ART. $9^{\circ}$ DA LINDB Às OBRIGAÇÕES CIVIS CONTRATUAIS

Danielle Cristina Lanius e Ivo Teixeira Gico Jr 


\title{
Mapping the Duties of Private Companies in International Investment Law*
}

\section{Mapeando os deveres das empresas privadas no Direito Internacional dos Investmentos}

Nitish Monebhurrun ${ }^{* *}$

\begin{abstract}
On the basis of notorious evidence of corporate misconduct and of the legal difficulty to ascertain private companies' liability in international law, this article seeks to map such companies' duties in international investment law. This is undertaken by perusing how this law field makes provision and room for the issue of corporate social responsibility. As such, a trend exists in recent investment agreements and also in the arbitral jurisprudence which oversees investors' malpractices so as to, firstly, foster a culture of corporate social responsibility and to, secondly, evaluate their intrinsic legal protection. The present article maps this general direction of duly considering investors' duties while assessing their claims and discusses the legal purpose(s) of the new reference to corporate social responsibility in international investment law.
\end{abstract}

Keywords: investors' duties, corporate social responsibility, clean hands.

\section{Resumo}

Com base em notórios casos de irresponsabilidade social corporativa e considerando a dificuldade que se tem no Direito Internacional para responsabilizar empresas privadas, esse artigo propõe um mapeamento dos deveres das empresas-investidoras no Direito Internacional dos Investimentos. Examinar-se-á, para tanto, como esse ramo de Direito tem absorvido a questão da responsabilidade social corporativa. Há, dessa feita, uma tendência nos recentes acordos de investimentos e também na jurisprudência arbitral para não menosprezar o comportamento socialmente irresponsável dos investidores. O objetivo é, nesse sentido, duplo. Pela integração do comportamento das empresas no debate, postula-se, por um lado, a criação de uma cultura de responsabilidade social das empresas e, por outro lado, avalia-se o teor real da proteção legal devida aos investidores. Logo, o presente artigo mapeará essa tendência de considerar os deveres dos investidores ao avaliar os seus pedidos na arbitragem internacional e discutirá, outrossim, a razão de ser jurídica dessa nova referência à responsabilidade social corporativa no Direito Internacional dos Investimentos.

Palavras-chave : deveres dos investidores, responsabilidade social corporativa, mãos limpas. 


\section{INTRODUCTION}

On the $25^{\text {th }}$ June 2014, a group of States - namely Ecuador, South Africa, Cuba, Venezuela and Bolivia - , championed the adoption of a binding treaty on Business and Human Rights ${ }^{1}$. Shortly after this initiative, the proposal was formalized in a resolution entitled "Elaboration of an international legally binding instrument on transnational corporations and other business enterprises with respect to human rights", adopted by the Human Rights Council ${ }^{2}$. The resolution kicked off (anew) the debate on this problematic which has, in itself, a rather long history and whose attempts of resolution have always been stillborn.

The discussions about the binding agreement are ongoing through the work of the Intergovernmental Working Group on Transnational Corporations and other Business Enterprises with Respect to Human Rights established by the Human Rights Council'3. They take stock of the Guiding Principles on Business and Human Rights ${ }^{4}$ — the Ruggie principles — with an aim to take matters forward towards an instrument having a mandatory power on transnational companies. Still in 2014, another group of States ${ }^{5}$ proposed a draft resolution on the implementation of the Guiding Principles to the Human Rights Council; one paragraph of the draft's preamble expresses the principal entanglement

1 Human Rights Council, "Elaboration of an international legally binding instrument on transnational corporations and other business enterprises with respect to human rights", Draft Resolution A/ HRC/26/L.22/Rev.1 [25/06/2014].

2 Human Rights Council, "Elaboration of an international legally binding instrument on transnational corporations and other business enterprises with respect to human rights", Resolution A/HRC/ $\mathrm{RES} / 26 / 9$ [14/07/2014].

3 Human Rights Council, "Report on the second session of the open-ended intergovernmental working group on transnational corporations and other business enterprises with respect to human rights", Resolution A/HRC/34/47 [04/01/2017] (Special rapporteur: María Fernanda Espinosa). See also: Olivier de Schutter, “Towards a New Treaty on Business and Human Rights", Business and Human Rights Journal, vol.1, no.1., 2015, pp. 41-67.

4 United Nations, "Guiding Principles on Business and Human Rights. Implementing the United Nations "Protect, Respect and Remedy" Framework", New York and Geneva, United Nations [2011], 35p. The Guiding Principles were endorsed by the Human Rights Council on the $6^{\text {th }}$ July 2011 in its resolution A/HRC/ RES/17/4 entitled "Human rights and transnational corporations and other business enterprises".

5 These countries are: Andorra, Argentina, Australia, Austria, Bulgaria, Colombia, France, Georgia, Ghana, Greece, Guatemala, Iceland, India, Lebanon, Liechtenstein, Mexico, New Zealand, Norway, Russian Federation, Serbia, Macedonia, and Turkey. lurking behind the current subject:

"Concerned at legal and practical barriers to remedies for business-related human rights abuses, which may leave those aggrieved without opportunity for effective remedy, including through judicial and non-judicial avenues, and recognizing that it may be further considered whether relevant legal frameworks would provide more effective avenues of remedy for affected individuals and communities [...]"'.

The main concern is the simple finding that economic activities of transnational companies may insidiously meander towards many non-economic components of the host States' society ${ }^{7}$ thereby causing considerable damage to the local population, environment, values or culture. The Chevron/Texaco investment in Ecuador — with its socio-environmental upheavals - in itself tellingly expresses the thorny issue of a long term corporate malpractice in so-called developing countries ${ }^{8}$. Chevron/Texaco's investment in the oil exploration sector had deleterious consequences on the environment through deforestation, river and soil pollution, and toxic waste spills in the Ecuadorian Amazon forest. This consequently affected human health and the local population has been diagnosed with illnesses like cancers, respiratory problems and other serious health complications. For these same reasons, the companies' activities encroached on the population's food security and access to drinking water. Last but not least, indigenous communities were forcefully displaced from their lands for the investment's well-being?

6 Human Rights Council, "Human rights and transnational corporations and other business enterprises", Draft resolution A/ HRC/26/L.1 [23/06/2014].

7 Mireille Delmas-Marty, Aux quatre vents du monde. Petit guide de navigation sur l'océan de la mondialisation, Paris, Seuil, 2016, p.62; Muthucumaraswamy Sornarajah, "Mutations of Neo-Liberalism in International Investment Law ", Trade Law and Development, vol.3, 2011, pp. 203-232.

8 See generally: Judith Kimerling, "Oil, Contact, and Conservation in the Amazon: Indigenous Huaorani, Chevron, and Yasuni”, Colorado Journal of International Environmental Law and Policy, vol.24, no.1, 2013, pp. 43-115; Eric David, Gabrielle Lefèvre, Juger les multinationales. Droits bumains bafoués, ressources pillées, impunité organisée, Bruxelles, Louvain, 2015, pp.28-30; Kate Miles, The Origins of International Investment Law. Empire, Environment and the Safeguarding of Capital, Cambridge, Cambridge University Press, 2013, pp. 140-146.

9 Sucumbios Provincial Court of Justice [Sole Chamber], Lawsuit No. 2003-0002 [Reporting Judge: Nícolas Zambrano Lozada]. See also: Eric David, Gabrielle Lefèvre, Juger les multinationales. Droits humains bafoués, ressources pillees, impunité organisée, Bruxelles, Louvain, 2015, pp.28-29; Kate Miles, The Origins of International Investment Law. Empire, Environment and the Safeguarding of Capital, Cambridge, Cambridge University Press, 2013, pp. 141-143; Maxi Lyons, "A Case 
There is, likewise, notorious evidence bearing testimony of corporate misconduct. This said, the present article does not have as main purpose reviewing all the relevant cases. The Business and Human Rights Resource Centre monitors the corporate social responsibility of companies throughout the world and offers an extensive list of cases on its website to which the reader can have easy access ${ }^{10}$. There is also considerable evidence of such adverse corporate impact in the legal literature ${ }^{11}$. The matter develops into a conundrum because of the frequent difficulty faced to determine the companies' liability or to obtain effective reparation in such cases. This can be related to complex corporate structure ${ }^{12}$ which sometimes makes it difficult for victims to climb up to the parent company to seek for reparation. The theory of separate corporate legal personality ${ }^{13}$ is here normally invoked by companies. This

Study in Multinational Corporate Accountability: Ecuador's Indigenous Peoples Struggle for Redress", Denver Journal of International Law and Policy, vol.32, 2004, pp. 701-732.

10 The Business and Human Rights Resource Centre profiles an extensive list of cases on its website: https://business-humanrights. org/en/corporate-legal-accountability/case-profiles/complete-listof-cases-profiled

11 See for example: Jennifer Zerk, "Corporate Liability for Gross Human Rights Abuses. Towards a Fairer and More Effective System of Domestic Law Remedies", Report prepared for the Office of the UN High Commissioner for Human Rights, 2014, 123p; Eric David, Gabrielle Lefèvre, Juger les multinationales. Droits humains bafoués, ressources pillées, impunité organisée, Bruxelles, Louvain, 2015, 190p; Kate Miles, The Origins of International Investment Law. Empire, Environment and the Safeguarding of Capital, Cambridge, Cambridge University Press, 2013, pp. 125-224; Delphine Couveinhes-Matsumoto, Les droits des peoples autocbtones et l'exploitation des ressoucres naturelles en Amérique latine, Paris, L'Harmattan, 2016, pp. 49-61; Michael Wright, "Corporations and Human Rights. A Survey of the Scope and Patterns of Alleged Corporate Human Rights Abuse", Corporate Social Responsibility Initiative, working paper $n^{\circ} .44$, Cambridge MA: John F. Kennedy School of Government, Harvard University, 2008, pp. 1-30; Lilian Aponte Miranda, "The Hybrid State-Corporate Enterprise and Violations of Indigenous Land Rights: Theorizing Corporate Responsibility and Accountability under International Law", Lewis \& Clark Law Review, vol.135, 2007, pp. 135-183; Maxi Lyons, "A Case Study in Multinational Corporate Accountability: Ecuador's Indigenous Peoples Struggle for Redress", Denver Journal of International Law and Policy, vol.32, 2004, pp. 701-732; Maria Júlia Gomes de Andrade et al., Inside the Vale of Mud: A Report on the Tailings Dam Collapse in Brazil, Rio de Janeiro, Justiça Global, 2016, 42p.; Manoela Carneiro Roland et al., Violation of Human Rights by Companies. The Case of the Açu Port, Juiz de Fora, HOMA-Human Rights and Business Centre, 2016, 22p.

12 Anna Beckers, Enforcing Corporate Social Responsiility Codes. On Global Self-Regulation and National Private Law, Oxford, Hart Publishing, 2015, p.11.

13 Stephen Tully, International Corporate Responsibility, Alphen Aan Den Rijn, Kluwer Law International, 2012, p.8 was, for instance, what happened in the Bhopal case in which the Union Carbide Company - incorporated in the United States of America - successfully argued that its Indian subsidiary, Union Carbide of India, was a separate legal entity for whose actions the parent company could not be held liable ${ }^{14}$. The Bhopal disaster was due to a toxic gas leak from a pesticide manufacturing factory owned by Union Carbide and operated by Union Carbide of India. The victims of the Chevron/ Texaco activities in Ecuador had to face this same difficulty of piercing the corporate veil in trying to enforce a decision of the Ecuadorian Supreme Court in Canada - a decision which condemned the company to a payment of damages of 9,51 billion dollars. The plaintiffs argued, amongst others, that the Chevron Corporation fully controlled its Canadian subsidiary, Chevron Canada Ltd. and that the global corporate structure had the same Board of Directors; the parent company could thus be "reached" through the subsidiary. Upholding the doctrine of corporate separateness, the Superior Court of Justice of Ontario declared that the Chevron Corporation and Chevron Canada Ltd. were, in law, two separate entities and that the latter could not be held liable for damages caused by the former ${ }^{15}$.

A similar debate arises when parent companies consider that they do not bear responsibility for damages caused by service providers or by outsourced companies, contending that the latter's activities escapes from the main entity's sphere of influence ${ }^{16}$. This happened, for example, after the collapse of the Rana Plaza in Dacca, Bangladesh. The Rana Plaza was home to garment factories manufacturing clothes for renowned brands and the building, left to crumble, did not minimally respect construction security requirements ${ }^{17}$; it was, moreover, revealed that some of the factories were oblivious in terms of basic labour laws ${ }^{18}$. Concerned companies, like

14 Union of India v. Union Carbide, United States Court of Appeal, Second Circuit, 809 F.2d 195 [14/01/1987]; Jagarnath Sabu, et al., v. Union Carbide Corporation and Madhya Pradesh State, United States District Court - Southern District of New York, Case no. 07 Civ. 2156 [30/07/2014].

15 See: Yaiguaje v. Chevron Corporation, 2017 ONSC 135 (CanLII) [20/01/2017], paras.57-60 (available at: http://canlii.ca/t/gx2x6).

16 Generally, on the sphere of influence, see: Gilles Lhuilier, Le droit transnational, Paris, Dalloz, 2016, p. 231.

17 Eric David, Gabrielle Lefèvre, Juger les multinationales. Droits humains bafoués, ressources pillees, impunité organisée, Bruxelles, Louvain, 2015, pp. 42-43.

18 Sherpa, "Affaire Auchan/Rana Plaza : de nouvelles preuves de violations des droits des travailleurs dans les usines sous-traitantes du distributeur", Press Release (20/10/2015) [available at : https:// 
Auchan, retorted that their duty of diligence did not extend that far in the supply chain ${ }^{19}$. And it is namely after this case that France adopted its famous statute on the duty of diligence of parent companies ${ }^{20}$.

The afore-described panorama dialectically bucks into the field of international investment law. Indeed, these same companies whose transnational activities allegedly or demonstrably have adverse socio-environmental impacts are potentially protected by a wide array of investment protection agreements. Said otherwise, in international law, the investor-company and its investment benefit from a consolidated legal bulwark to protect its activities but have, in international law, very few obligations vis-à-vis the host States and their population $^{21}$ : there is a power relationship in disequilibrium with a hyper-protected corporate world on one side, and sometimes vulnerable communities on the other $^{22}$; moreover, the domestic legal systems are not always effective when it comes to dealing with private companies liability; besides the same State may sometimes have conflicting commitments in international law whereby the legal protection of foreign investors

www.asso-sherpa.org/affaire-auchan-rana-plaza-de-nouvellespreuves-de-violations-des-droits-des-travailleurs-dans-les-usinessous-traitantes-du-distributeur].

19 Nicolas Cuzacq, "Panorama en droit économique", in, Kathia Martin-Chenut, René de Quenaudon, La RSE saisie par le droit. Perspective interne et internationale, Paris, Pédone, 2016, pp. 107-108.

20 Statute $n^{\circ} 2017-399$ on the Duty of Diligence of parent companies (in French, loi relative au devoir de vigilance des sociétés mères et des entreprises donneuses d'ordre) [27/03/2017] (available at: https:// www.legifrance.gouv.fr/eli/loi/2017/3/27/2017-399/jo/texte). See also : Marie-Ange Moreau, "Le devoir de vigilance", Droit social, no.10, October 2017, p. 792 et seq.

21 Patrick Juillard, "Le système actuel est-il déséquilibré en faveur de l'investisseur privé étranger et au détriment de l'État d'accueil ? ", in, Charles Leben (org.), Le contentieux arbitral transnational relatif à l'investissement. Nouveaux Développements, Paris, L.G.D.J., 2006, pp. 190-191; Muthucumaraswamy Sornarajah, " Power and Justice: Third World Resistence in International Law ", Singapore Yearbook of International Law, vol.10, 2006, p. 32; Patrick Dumbery, Gabrielle Dumas-Aubin, "How to Impose Human Rights Obligations on Corporations Under Investment Treaties?", Yearbook of International Investment Law and Policy, vol.4, 2012, p. 569; Kartsen Nowrot, "How to Include Environmental Protection, Human Rights and Sustainability in International Investment Law?", Journal of World Investment and Trade, vo.15, 2014, p. 619. for a more nuanced point of view, see: Jorge Viñuales, "Invest Diligence in Investment Arbitration: Sources and Arguments", ICSID Review, vol.32, n.2, 2017, p. 367.

22 See: Working Group on the issue of human rights and transnational corporations and other business enterprises (Human Rights Council), Report on Promotion and protection of human rights: buman rights questions, including alternative approaches for improving the effective enjoyment of buman rights and fundamental freedoms, Document A/72/162 [18/07/2017], p. 9 . must be articulated with environmental, human rights or health protection ${ }^{23}$. Traditionally, investment agreements ${ }^{24}$ have been solely moulded to protect transnational investments of private companies. Very often, investment agreements models were drafted by industrialised States and later on signed with developing ones with minimum or no negotiations ${ }^{25}$. The latter group of countries accepted the 'proposed' agreements under the belief that these would foster more investments in their territory, thereby enabling them to achieve their quest of development ${ }^{26}$. Foreign investment promotion was construed through the optic of investment protection and the investment agreements models reflected the perspective and interests of capital exporting countries in the context of a winning free market economy in which the market often makes the law $^{27}$. The watchword was therefore a minimum restriction to the free circulation of capital and investments. And any kind of obligation, duty or performance imposed upon investors could eventually contradict the economic logic of free circulation, the political will of importing and exporting investments, and the legal protection offered by investment agreements.

Authors like Theodore Lewitt or Milton Friedman vehemently criticised the doctrine of corporate social responsibility, defending that it constituted an undesirable intrusion in business whose main purpose is to maximise profits and not to substitute the State in social matters and public policy ${ }^{28}$. Interestingly, however, in

23 See, for instance, the debate in the Philip Morris case: Philip Morris Brands Sàrl, Philip Morris Products S. A. and Abal Hermanos S.A. v. Oriental Republic of Uruguay, ICSID Case No. ARB/10/7, Award (09/07/2016).

24 Most of the international investment agreements are available at: http://investmentpolicyhub.unctad.org/IIA

25 Patrick Juillard, "Le système actuel est-il déséquilibré en faveur de l'investisseur privé étranger et au détriment de l'État d'accueil ? ", in, Charles Leben (org.), Le contentieux arbitral transnational relatif à l'investissement. Nowveaux Développements, Paris, L.G.D.J., 2006, pp. $190-$ 191; Nitish Monebhurrun, La fonction du développement dans le droit international des investissements, Paris, L'Harmattan, 2016, pp. 72-73.

26 For a critical view on this question, see : Nitish Monebhurrun, La fonction du développement dans le droit international des investissements, Paris, L'Harmattan, 2016, pp. 68-69.

27 William Bourdon, Yann Queinec, Réguler les entreprises transnationales. 46 propositions, Paris, Sherpa, Décembre 2010, p. 13 [available at : https://www.asso-sherpa.org/wp-content/uploads/2013/11/ CDP-francais.pdf]

28 See : Theodore Lewitt, "The Dangers of Social Responsibility", Harvard Business Review, September-October 1958, pp. 41-50; Milton Friedman, "The Social Responsibility of Business is to Increase Its Profits", The New York Times Magazine, 16 septembre 1970 [available at: http://www-rohan.sdsu.edu/faculty/dunnweb/rprn- 
the fifties, the concept of corporate social responsibility was used, namely in the United States of America, as an instrument of propaganda of positive capitalism... a doctrine of friendly and caring business - against the communist ideology $y^{29}$. From the sixties to the eighties, the very concept of corporate social responsibility, that of investors' duties, were very incipient, at least in international law. In international politics, concern was raised about the companies' social responsibility after a famous speech delivered by Chilean President Salvador Allende on the $4^{\text {th }}$ December 1972 before the United Nations' General Assembly on the devastating consequences of transnational companies' activities ${ }^{30}$. But still today, on concrete terms, corporate social responsibility often amounts to a procrastinating debate ${ }^{31}$.

Investors' duties, under the logic of corporate social responsibility, mean the measures imposed on or recommended to companies so as to mitigate the negative human, environmental and social impacts of their activities $^{32}$; the idea is to transcend the inner corporate structure and the sole shareholder's interests, thereby setting up a business intelligence which is able to envisage and eventually prevent a company's adverse social impacts $^{33}$. The duty consists of adopting a corporate behaviour to mitigate these impacts so as to attain a level of social responsibility which, when necessary, goes beyond that required by the host State and which must

ts.friedman.dunn.pdf].

29 Jean-Pascal Gond, Jacques Igalens, La responsabilité sociale de l'entreprise, Paris, PUF, 2008, p. 16.

30 Salvador Allende, "Speech before the United Nations' General Assembly", 4 ${ }^{\text {th }}$ December 1972 (excerpts available at: http://www. rrojasdatabank.info/foh12.htm).

31 Harwell Wells, «The Cycles of Corporate Social Responsibility: An Historical Retrospective for the Twenty-first Century", Kansas Law Riew, vol.51, 2002, p. 78.

32 United Nations Environmental Program, Corporate Social Responsibility and Regional Trade and Investment Agreements, UNEP, 2011, p. 13; Amiram Gill, "Corporate Governance as Social Responsibility: A Research Agenda", Berkley Journal of International Law, vol.26, no.2, 2008, pp. 453-454; Steven R. Ratner, "Corporations and Human Rights: A Theory of Legal Responsibility", Yale Law Journal, vol.111., 2001, pp. 443-545; Erik Assadourian, "Transforming Corporations", in, Linda Starke (org.), The State of the World 2006. A Worldwatch Institute Report on Progress Toward a Sustainable Society, London, WW. Norton and Company, 2006, p. 172; Kate Miles, The Origins of International Investment Law. Empire, Environment and the Safeguarding of Capital, Cambridge, Cambridge University Press, 2013, p. 218; Stephen Tully, International Corporate Responsibility, Alphen Aan Den Rijn, Kluwer Law International, 2012, pp. 20-22.

33 Harwell Wells, «The Cycles of Corporate Social Responsibility: An Historical Retrospective for the Twenty-first Century", Kansas Law Riew, vol.51, 2002, p. 78. equally apply to all the companies of the same group independently of their business location ${ }^{34}$. These duties can be voluntarily set by the companies themselves in the sense of a self-regulation; and, as mentioned, there is also considerable effort being deployed for these to be provided for in binding legal instruments.

The United Nations tentatively worked on a draft code of conduct for transnational corporation through its Centre on Transnational Corporations in the seventies $^{35}$. Such efforts have, for the moment, been vain within the ambit of the United Nations Organisation. Despite the adoption of the ten principles of a Global Compact in $2000^{36}$, these remain very general in their formulation and are, furthermore, voluntary when it comes to their effective implementation by companies. The same comment applies to the Organisation for Economic Cooperation and Development's Guidelines for Multinational Enterprises $^{37}$ or the so-called Ruggie Principles ${ }^{38}$. These initiatives surely constitute small hesitant steps towards the long run construction of a consolidated corporate social responsibility legal regime. But the long run always appears as an eternity when the subject is private companies' responsibility in international law. The normativity in this field seems to become liquid, with dominant actors - transnational corporations - capitalizing on a system of self-regulation ${ }^{39}$ in a sort of untouchable ivory tower, while being sometimes theatrically judged by Opinion Tribunals ${ }^{40}$ with no real legal effects.

34 Hervé Ascensio, "Le pacte mondial et l'apparition d'une responsabilité internationale des entreprises", in, Laurence Boisson de Chazournes, Emmanuelle Mazuyer, Le Pacte mondial - 10 ans après. The Global Compact-10 Years After, Bruxelles, Bruylant, 2011, p. 169. 35 A 1983 version of the Code of conduct is available at: http:// investmentpolicyhub.unctad.org/Download/TreatyFile/2891. For more information, see: Karl P. Sauvant, "The Negotiations of the United Nations Code of Conduct on Transnational Corporations Experience and Lessons Learned", Journal of World Investment and Trade, vol.16, 2015, pp. 11-87.

36 Global Compact, adopted on the $26^{\text {th }}$ July 2000 (available at: https://www.unglobalcompact.org/what-is-gc/mission/principles).

37 The guidelines are available at: http://www.oecd.org/daf/inv/ mne/48004323.pdf. See also: Jorge Viñuales, "Invest Diligence in Investment Arbitration: Sources and Arguments", ICSID Review, vol.32, no.2 2017, p. 349.

38 United Nations, "Guiding Principles on Business and Human Rights. Implementing the United Nations "Protect, Respect and Remedy" Framework", New York and Geneva, United Nations [2011], 35p.

39 In a similar sense: Zygmunt Bauman, La cultura en el mundo de la modernidad líquida, Mexico, FCE, 2013, p. 52.

40 See: International Monsanto Tribunal, Advisory Opinion (18/04/2017) [available at: http://en.monsantotribunal.org/upload/asset_cache/189791450.pdf]. 
This article will not indulge in a normative posture to postulate how the law should be on these questions. Having international investment law as a study background, it will instead examine if the generous protection granted to investors can be articulated with their duties. To this interrogation, the working and analysis method consist of scrutinising how and to what extent investment agreements and the arbitral jurisprudence provide for investors' duties. The objective of this article is therefore to critically map and categorise such duties as they appear in international investment law. Accordingly, the study shows that some recent investment agreements indeed provide for investors' social responsibility; as such, the latter potentially becomes a new yardstick against which to measure the legal protection due to companies (Chapter 1). Similarly, an analysis of the arbitral jurisprudence reveals a set of techniques to map the investors' corporate social behaviour which consequently act as a benchmark when it comes to evaluate the extent of their legal protection (Chapter 2).

\section{Providing for Investor's Duties in Investment Agreements as a New Yardstick for their Protection}

A small constellation of companies' duties has started to appear in investment agreements and even if they are normally presented as recommendations (2.1.), they can be construed as a parameter for investors' legal protection (2.2.).

\subsection{Investors' Duties Entrenched in Investment Agreements as Recommendations}

These recommendations are coined in a twofold manner. Firstly, they are formulated as per a top-down logic: this means that they are primarily addressed to signatory States which must encourage companies investing on their territory to adopt corporate social responsibility standards (2.1.1.). Secondly, the recommendations follow a - more recent - bottom-up pathway being addressed directly to the investors (2.1.2.).

\subsubsection{Recommending duties to investors throu- gh States under a top-down logic}

Some treaties address the issue of investors' corporate behaviour in the host States but leave to the latter the duty of adopting all necessary measures for such purposes. It is well-known that the great majority of investment agreements state that investments must be undertaken in conformity with the Host State's local law: in a nutshell, an illegally constituted investment cannot be protected by an investment agreements. This, as per some tribunals, can be considered as a non-written rule of international investment law ${ }^{41}$. This rule however generally refers to the company's establishment in the Host State.

On other grounds, provisions have started to appear in investment agreements that make room for corporate social responsibility during the investment's implementation. Their formulation varies according to the agreements with a language which can be mandatory or unbinding. For instance, the bilateral investment agreement signed between Canada and Mongolia on the $8^{\text {th }}$ September 2016 states:

"Each Party should encourage enterprises operating within its territory or subject to its jurisdiction to voluntarily incorporate internationally recognized standards of corporate social responsibility in their practices and internal policies, such as statements of principle that have been endorsed or are supported by the Parties. These principles address issues such as labour, the environment, buman rights, community relations and anti-corruption. The Parties should remind those enterprises of the importance of incorporating such corporate social responsibility standards in their internal policies." ${ }^{42}$

A similar provision exists in the recent investment or free-trade agreements signed by States like Canada,

41 SAUR International S. A. v. Argentina, ICSID n ${ }^{\circ} 04 / 4$, Decision on Jurisdiction and Liability (6/06/2012), para. 308; Gustav F W Hamester GmbH \& Co KG v. Ghana, ICSID n ${ }^{\circ}$ ARB/07/24, Award (18/06/2010), paras.123-124; Mamidoil Jetoil Greek Petroleum Products Société S.A. v. Albania, ICSID no ARB/11/24, Award (30/03/2015), para. 359.

42 Agreement Between Canada and Mongolia for the Promotion and Protection of Investments (08/09/2016), art.14. 
Colombia, the Netherlands ${ }^{43}$, Chile ${ }^{44}$, Singapore ${ }^{45}$ or by the European Union ${ }^{46}$, some of which are still awaiting ratification. The signatory States are expected to foster a corporate social responsibility practice on their territory and can, as per these agreements, only encourage foreign investors to fine-tune their activities in order to mitigate impacts on the environment, on human rights, on local communities and to abstain from practices of corruption. The internationally recognised standards are, for example, the OECD guidelines, the International Labour Organization Declaration on Fundamental Principles and Rights at Work ${ }^{47}$, the Global Compact and more recently, the Ruggie principles. As such, the corporate social responsibility initiative emanates from the State and, if successful, drips down to the companies. But even so, such practices by companies remain largely voluntary at this level. Investors, via their Host States, are invited to adopt a corporate social behaviour and can, needless to say, decline the invitation. Similarly, States might fear losing their appeal vis-à-vis foreign investors if they fanatically indulge in imposing duties to

43 See for example for Canada: Bilateral Investment Agreement signed with: Guinea (27/05/2015), art.16; Burkina Faso (20/04/2015) art.16; Cameroon (03/03/2014) art.15; Ivory Coast (30/11/2014) art.15; Mali (28/11/2014) art.15; Nigeria (06/05/2014) art.16; Senegal (27/11/2014) art.16; Serbia (01/09/2014) art.16; Benin (09/01/2013) arts. 4, 16. Free-Trade Agreements signed with: The European Union (30/10/2016), arts. 24.12[1](c), 25.4 [2](c); the Trans-Pacific Partnership (04/02/2016), art.9.17; South Korea (22/05/2014) art.8.16; Honduras (05/11/2013) art.10.16; Panama (14/05/2010) art.9.17; Colombia (21/11/2008) art.816; Peru $(29 / 05 / 2008)$ art. 810.

For Colombia, see: bilateral investment agreement signed with France (10/07/2014), art.11; with Brazil (09/10/2015), art.13; and free-trade agreements signed with Panama (20/09/2013), art.14; Costa Rica (22/05/2013) art.12.9; Canada (21/11/2008), art.816; with the European Union and Peru (26/06/2012), art.271/3.

For the Netherlands, see: bilateral investment agreement signed with the United Arab Emirates (26/11/2013), art.2 (3).

44 Investment Agreement between the Hong Kong Special Administrative Region of the People's Republic of China and Chile (18/11/2016), art.16; Free-Trade Agreement between Chile and Uruguay (04/10/2016), art.11.8, art.12.6.

45 Investment Agreement between Singapore and Nigeria (04/11/2016), art.11.

46 Free-Trade Agreement with the SADC (10/06/2016), art. 11 (3) [c] or with Canada (30/10/2016), art. 24.12[1](c), 25.4 [2](c); with Kazakhstan (21/12/2015), art. 148 (3); with Georgia (27/06/2014), art. 231 (e), art. 348, art. 349, art. 352; with Moldavia (27/06/2014), art. 35, art 367 (e); with South Korea (06/10/2010), art. 13 [6] (2); with Ukraine (27/06/2014), art. 422.

47 International Labour Organization Declaration on Fundamental Principles and Rights at Work [18/06/1998] [available at: http:/ / www.ilo.org/wcmsp5/groups/public/---ed_norm/---declaration/ documents/publication/wcms_467653.pdf] these companies. Resultantly, there might be more something of an appearance of corporate social responsibility than an intrinsic concern which would normally be displayed by binding rules or by an enforcement system. Consequently, their intrinsic value and utility can, to some extent, be questioned. This scepticism is exacerbated most of all when some investment agreements specifically highlight that issues related to the corporate social responsibility clause cannot be a contentious subject submitted to an arbitral tribunal ${ }^{48}$. This, of course, raises the question of their very ratio legis.

Some countries like Canada and Colombia coined a reporting mechanism in the sense of a Human Rights impact assessment. The idea, intellectually and methodologically interesting, is to measure the impact of business activities on Human Rights; such reporting could technically act as a barometer of corporate social behaviour and enable to identify eventual flaws in business practices. The two States thereby adopted an Agreement Concerning Annual Reports on Human Rights and Free Trade Between Canada and the Republic of Colombia with the objective of assessing the effects "of the measures taken under the Free Trade Agreement between Canada and the Republic of Colombia on human rights in the territories of both Canada and the Republic of Colombia"49. Until now, Canada submitted six reports to the House of Commons and to the Senate (from 2012 and 2016) ${ }^{50}$. These however remain globally vague and do not reveal a consolidated regime of corporate social responsibility within the ambit of business and human rights ${ }^{51}$.

If from a cynical perspective the debate hence see$\mathrm{ms}$ to boil down to an eternal recurrence, another com-

48 Agreement Between Canada and Mongolia for the Promotion and Protection of Investments (08/09/2016), art.20 (1); Agreement Between Canada and Guinea for the Promotion and Protection of Investments Guinea (27/05/2015), art.21 (1); Brazil-Chile ACFI (24/11/2015), annex 1, art.1 (2); Brazil-Colombia ACFI (09/10/2015), art. 23 (3); Investment agreement between the Hong Kong Special Administrative Region of the People's Republic of China and Chile (18/11/2016), art. 21[1] (a) (i).

49 Agreement Concerning Annual Reports on Human Rights and Free Trade Between Canada and the Republic of Colombia (27/05/2010), [available at: http:/ / www.treaty-accord.gc.ca/text-texte.aspx?id=105278], art. 1(1).

50 These reports are available at: http://www.canadainternational.gc.ca/colombia-colombie/bilateral_relations_bilaterales/hrftco_2012-dple.aspx?lang=eng

51 James Rochlin, “A golden opportunity lost: Canada's Human Rights Impact Assessment and the Free Trade Agreement with Colombia", The International Journal of Human Rights, vol.18, no.4/5, 2014, pp. 545-566. 
prehension of the matter still remains possible. There is no doubt that corporate social responsibility in the abovementioned agreements enters the realm of soft law. Such soft formulation can however be the initial steps for the creation of corporate social responsibility and of investors' duties culture in international investment law. For many decades, investment law had the only vocation of protecting foreign investors - and, of course, this is not likely to change drastically. Yet, if this law field is to incorporate other priorities or other values, this process forcefully requires a period of adaptation to enable the cultural incorporation of corporate social responsibility. In other words, it is unlikely and highly unrealistic that a drastic conversion - of States and of companies — to corporate social responsibility would occur overnight under the aspect of a binding legal rule. There are many political, economic and social forces to be dealt with and conciliated in this debate. Any radical or pugnacious position would certainly be counterproductive. The soft law regime approach is certainly not the most immediately efficient but it can be argued that it constitutes a first stepping stone towards the construction and diffusion of corporate social responsibility practices under a policy of small steps. And in this sense, a new step has effectively been hurdled considering that provisions directly addressed to investors on their corporate duties characterise a small bundle of new investment agreements.

\subsubsection{Recommending duties directly to inves- tors under a bottom-up logic to foster the crea- tion of a corporate social responsibility culture}

Every internationalist jurist is acquainted to the classicism according to which legal persons, like private companies, are deprived of a legal personality in international law. This said, it cannot be ignored that many private companies are economically more powerful than a good number of States $^{52}$, without mentioning that their economic activities can sometimes be detrimental to the local population, as explained in the introduction of this article. It would therefore be a lure to (still) consider that private companies having trans-

52 Brian Roach, "Corporate Power in a Global World", Global Development and Environment Institute Working Paper, 2007, p. 5 [available at: http://www.ase.tufts.edu/gdae/education_materials/modules/ Corporate_Power_in_a_Global_Economy.pdf]; Noreena Hertz, The Silent Takeover. Global Capitalism and the Death of Democracy, London, Arrow, 2002, p. 43. national economic activities bear absolutely no international responsibility if they happen to cause a social, human or environmental damage. The status quo will prevail only if the legal doctrine maintains a complacent or an orthodox position. The legal conscience on this issue is undeniable. It is worth recalling that the present debate has been amplified, going beyond private companies, to include the social responsibility of non-governmental organisations. The National Contact Point of the OECD in Switzerland has, for instance, accepted a claim against the World Wild Fund for Nature International (WWF) for human rights — indigenous rights - violation in Cameroon. The claim was lodged by another NGO, Survival International, against WWF for violation of the OECD Guidelines for Multinational Enterprises; the WWF is allegedly suspected to have violated the land rights of the Baka 'Pygmy' People ${ }^{53}$ and its size and influence rendered it tantamount to a multinational company.

In this context of great concern about the social impacts of transnational corporations, it is therefore not surprising to see the premises of investors' duties, via the institution of corporate social responsibility addressed directly to companies, in some investment agreements. And it can be claimed that this trend will be followed in future investment agreements. The Brazilian Agreements on Cooperation and on the Facilitation on Investments (ACFI) ${ }^{54}$ are here topical. They contain very detailed recommendations in a specific chapter or in an annex entitled "Corporate Social Responsibility. The provisions relate to the following: environment protection and clean technology; respect of human rights; local development and cooperation with local communities; formation of human capital; respect of local law and regulations in the field of health, security, environment

53 Details about the pending case are available at: https://www. oecdwatch.org/cases-fr/Case_457.

Survival International submission file is available at: http://assets. survivalinternational.org/documents/1527/survival-internation-vwwf-oecd-specific-instance.pdf

54 Generally, on the ACFIs see: Nitish Monebhurrun, "Novelty in International Investment Law: The Brazilian Agreement on Cooperation and Facilitation of Investments as a Different International Investment Agreement Model", Journal of International Dispute Settlement, vol.8, 2017, pp. 77-100; Fabio Morosini and Michelle Ratton Sanchez Badin, 'The Brazilian Agreement on Cooperation and Facilitation of Investments (ACFI): A New Formula for International Investment Agreements?' Investment Treaty News (4 August 2015) https://www.iisd.org/itn/2015/08/04/the-brazilian-agreementon-cooperation-and-facilitation-of-investments-acfi-a-new-formula-for-international investment-agreements/. 
and labour laws; practices of self-regulation to make the companies' activities socially acceptable; training of employees to incorporate the culture and the practices of corporate social responsibility; non-discrimination of employees having reported the companies' socially irresponsible and illegal practices to the local authorities; the implementation of corporate social responsibility practices within the companies' sphere of influence; the respect of local political affairs ${ }^{55}$. There is a manifest will to extract companies from a close, clinically isolated circuit in order to make their investing activities socially acceptable ${ }^{56}$ while tentatively building bridges between foreign investment and local population.

Such provisions do not characterise only the new Brazilian agreements. The Intra-Mercosur Investment Facilitation Protocol contains an article 13 entitled "Obligations of Investors" which States that companies must - the language is here mandatory — abide to local laws and regulations related to investment and taxation; it also states that investors must not indulge in acts of corruption during their activities ${ }^{57}$. Article 14 of the same protocol provides for corporate social responsibility in a way remindful of the Brazilian investment agreements, that is, with a list of recommendations which the investors can incorporate in their activities. The general logic and ratio legis of these recommendations can also be construed as per the proposed idea ${ }^{58}$ of investors' duties culture creation: investing companies must conspicuously frame their economic activities following domestic legislation; however, when the latter is still incipient in terms of corporate social responsibility, it is expected that companies consider the recommendations set in the investment agreements so as to be more rigorous than the local laws. There is thus an additional effort expected from the investors. For instance, the Morocco-Nigeria bilateral investment agreement states that "[i] $n$ addition to the obligation to comply with all applicable laws and regulations of the Host State

55 Brazil-Anglo ACFI (01/04/2015), art. 10, annex II; BrazilMozambique ACFI (30/03/2015), art.10, annex II; Brazil-Mexico ACFI (26/05/2015), art.13; Brazil-Malawi ACFI (25/06/2015), art.9; Brazil-Chile ACFI (24/11/2015), art.15. See also the economic and commercial agreement between Brazil and Peru (29/04/2016), art. 2.13.

56 On social acceptability, see: Corinne Gendron, "Penser l'acceptabilité sociale : au-delà de l'intérêt, les valeurs » (2014), Revne internationale Communication sociale et publique, vol.11, 2014, pp. 117-29. 57 Intra-Mercosur Investment Facilitation Protocol (07/04/2017), art. 13. [The Protocol has not yet been ratified].

58 See 1.1.1. supra. and the obligations in this Agreement, and in accordance with the size, capacities and nature of an investments, and taking into account the development plans and priorities of the Host State and the Sustainable Development Goals of the United Nations, investors and their investments should strive to make the maximum feasible contributions to the sustainable development of the Host State and local community through high levels of socially responsible practices" 59 . The same treaty further highlights that the International Labour Organisation's Tripartite Declaration on Multinational Investments and Social Policy must be applied and informs that the investors must always endeavour to maintain their corporate social responsibility standards at the same level as those generally in force ${ }^{60}$. The agreement moreover makes provision for a prior social and environmental impact assessment ${ }^{61}$ whereby the investors must measure - and thus minimise - all negative social and environmental externalities potentially entrenched in the investments; concerning more specifically the environmental impact assessment, it is mentioned that the companies must apply the rules thereto related of either the host or the home State, whichever is the more protective. Direct obligations on corruption issues are also addressed to investors in the Morocco-Nigeria investment agreement ${ }^{62}$. The language of this agreement is interesting for being mandatory: article 18 is, for example, entitled "Post-Establishment Obligations" and article 20, "Investor liability". These are not mere recommendations on corporate social responsibility but binding obligations. Article 18 states that the foreign investing companies must adopt an environmental management system — certified by or tantamount to the ISO 14001 (on environmental management) when the activity is a high-risk one ${ }^{63}$. Investors must similarly make sure that their investments are respectful of human rights and labour laws and standards ${ }^{64}$ and that a dialogical spirit exists between them and the local population ${ }^{65}$. When

59 Bilateral Investment Agreement between Morocco and Nigeria (03/12/2016), art.24 (1).

60 Bilateral Investment Agreement between Morocco and Nigeria (03/12/2016), art.24 (2), (3).

61 Bilateral Investment Agreement between Morocco and Nigeria (03/12/2016), art.14.

62 Bilateral Investment Agreement between Morocco and Nigeria (03/12/2016), art.17.

63 Bilateral Investment Agreement between Morocco and Nigeria (03/12/2016), art.18(1).

64 Bilateral Investment Agreement between Morocco and Nigeria (03/12/2016), art.18 (2), (3), (4).

65 Bilateral Investment Agreement between Morocco and Nigeria (03/12/2016), art.19 (1) (b). 
the standards for such a dialogue are inexistent or insufficient, the Joint Committees instituted by the agreement have the power to elaborate appropriate ones ${ }^{66}$. The introduction of this article pointed out some cases in which capturing multinational companies' liability for damages caused to the local population of the host States was utterly difficult. Article 20 of the Morocco-Nigeria investment agreement proposes an interesting tool to minimise the possibilities of escaping from civil responsibility in such cases. It specifies that a company can be sued before and held liable by the tribunals of its home State for a damage caused in the host State. This provision is a real innovation in the field of international investment law and in that of corporate social responsibility. If used, it might act as a bar to the oft-invoked forum non conveniens argument or that of the corporate veil. In the same line of innovations, the agreement also credits the host State with a right to information: it can, accordingly, ask potential investors (or their home States) relevant information on their practices of healthy corporate governance ${ }^{67}$. In other words, investors resultantly have here a duty of information towards the State: if solicited, they must inform the host State on the history of their corporate social behaviour. Provisions addressing direct recommendations or duties to investors also appear in the Iran-Slovakia investment agreement $^{68}$, in the Argentina-Qatar agreement ${ }^{69}$, in the 2015 Indian investment agreement model $^{70}$ or in the new 2017 Colombian Investment Agreement model ${ }^{71}$.

66 Bilateral Investment Agreement between Morocco and Nigeria (03/12/2016), art.19 (1) (c).

67 Bilateral Investment Agreement between Morocco and Nigeria (03/12/2016), art.21 (1).

68 Bilateral Investment Agreement between Iran and Slovakia (19/01/2016), art.10 (3)

69 Bilateral Investment Agreement between Argentina and Qatar (06/11/2016), art.12.

702015 Indian investment agreement model, art. 9 (contains obligations addressed to investors in matters of corruption practices); art.12 (contains obligations addressed to investors to abide to local laws relating, amongst others, to human rights, environment and labour protection; the same article also obliges investors to adopt national and international recognised standards of corporate governance).

71 The author had access to the 2017 Colombian investment model which has not yet been published. One article - with no number yet - states: "Claimant Investors shall respect the probibitions established in international instruments, to which any Contracting Party is or becomes a party, pertaining to buman rights and the environment. A Claimant Investor shall accept the aforementioned probibitions as mandatory throughout the making of its investment and its operation in the Host Party's Territory in order to submit a claim to a Court or an Arbitral Tribunal pursuant to SECTION DD]-INVESTOR-STATE DISPUTE SETTLEMENT."
Even if the incorporation of investors' duties in investment agreements could obviously be drafted in a more rigorous way, the abovementioned examples remain useful to establish, even exploratorily, the grounds of a 'normality' of juxtaposing in the same agreement provisions on investors' protection and on their duties. The trend is, of course, new but it constitutes a clear message sent to transnational companies: that their corporate social conduct and eventually imposed obligations will potentially be considered so as to construe their due legal protection ${ }^{72}$. The duties are perhaps presented as voluntary ones, but the presence of corporate social responsibility in the mentioned agreements is not innocent and is not deprived of purpose. And it can be postulated that, if consolidated and repeated in future investment agreements, it will, in the longer run, act as a condition as per which the protection due to investors could be measured; this, it is argued, could contribute to build a minimum standard of corporate diligence.

\subsection{Investors' Duties as a means to construe the extent of their legal protection: Postulating the construction of a minimum standard of corporate social diligence}

As there once arose a debate on whether there exists a minimum standard of treatment ${ }^{73}$, an analogy can be outlined on the existence of an expected minimum level of corporate social diligence on the part of transnational companies which are protected by a constellation of investment agreements. And the question which can here be asked is whether a company which has been neglectful or which has not shown any diligence in ter$\mathrm{ms}$ of an expected corporate social behaviour set in investment agreements can still use the latter as a legal shelter in case of disputes with their host States. Accordingly, the trend of including investors' commitments in investment agreements - or of framing treaties or guiding principles on business and human rights is not deprived of sense and purpose. It materialises a growing concern about corporate impunity and, in this sense, sketches a new, more nuanced, landscape of in-

72 This shall be explored infra.

73 On the minimum standard of treatment, see: OECD, "Fair and Equitable Treatment Standard in International Investment Law", OECD Working Papers on International Investment, 2004/03, OECD Publishing, pp.8 et seq.; Rudolf Dolzer and Christoph Schreuer, Principles of International Investment Law, New York, Oxford University Press, 2009, pp. 134 et seq. 
ternational investment law whereby the applicable law does not unconditionally focus on investors' protection. The law thus strives to foresee investors and their activities and impacts in a broader social context. The inclusion of an expected corporate social responsibility of companies in investment agreements has arguably set the foundation and the first steps for the - surely slow - construction of a doctrine of a minimum standard of corporate social diligence: under this assumption, investors will have to be minimally (socially) diligent to claim the application of an investment agreement. If not, the provisions on the standards of corporate social responsibility would be of no use at all, they would be plainly ornamental and this, surely, is not the will of signatory States. Accordingly, the very legal purpose of these provisions can be examined.

A minima, such purpose is twofold. There is firstly the will, on the part of signatory States, that companies voluntarily incorporate such standards to articulate their activities with other values, may these be the respect of the environment, of human rights, of local communities and culture, of ethics and transparency. The first purpose is hence behavioural: companies are expected to adjust their corporate behaviour in a less egocentric fashion to mitigate the negative impacts of their activities. They are expected to be more diligent, more conscientious and to develop, over time, a culture of corporate social responsibility. Secondly, the reference to investors' duties and corporate social responsibility must not be excised from the other parts of the agreements. It is here claimed that such reference can be invoked to construe the provisions on the standards of treatment and of protection of investors. In other words, the legal protection due to foreign investors can be measured in the light of their corporate social behaviour. This implies giving a purposeful effect, a raison d'etre to the articles on investors' duties. They are indeed inserted in a particular textual context and must, for this reason, be read in consonance with the standards of investment protection. Besides investment protection and promotion, the preambles of some of the abovementioned agreements put corporate social responsibility as an objective and as means of equilibrium between the distributions of rights and duties of the concerned stakeholders $^{74}$. Resultantly, provisions on corporate so-

74 See for instance: Bilateral Investment Agreement between Morocco and Nigeria (03/12/2016); Intra-Mercosur Investment Facilitation Protocol (07/04/2017); Bilateral Investment Agreement cial responsibility can be used as a means of contextual interpretation of substantial investment protection standards as per article 31 of the Vienna Convention on the Law of Treaties (1969). This would enable these provisions to deploy practical effects and thus, not become a dead letter; there is, generally speaking, reasonable jurisprudence on contextual interpretation in international law and this applies to international investment law $^{75}$.

As such, even if some investors' commitments are formulated as recommendations, it does not necessarily mean that they are deprived of legal effects. It is true that some of the investment agreements state that the provisions on corporate social responsibility cannot be the object of dispute resolution ${ }^{76}$. It can however be claimed that invoking corporate social responsibility clauses during an eventual dispute settlement procedure will not, in itself, be the object of the dispute. The latter will still be related to a violation of a substantial investment protection provision. In any case, the investor is in most cases - except in rare counterclaims - the claimant and thus largely determines the object of the dispute which clearly focuses on violations of substantial investment protection standards; the State does not and will not have a great leeway to permanently and solely move the spotlight on the question of the company's behaviour. As stated, the relevant articles on corporate social responsibility will merely act as a means of interpretation and will not dominate the main debate. It would be a means to contextually enlighten and measure the extent of investors' effective protection by not overlooking the nature of their corporate social behaviour. This would constitute an indirect manner to help build up a culture of investors' duties and awareness of the latter. And, from another perspective, the investors will also be able to invoke the corporate social respon-

between Iran and Slovakia (19/01/2016).

75 Competence of the ILO to Regulate Incidentally the Personal Work of the Employer, PCIJ, Advisory Opinion, Series B, no.13 (23/07/1926), p. 19; Free Zones of Upper Savoy and the District of Gex, PCIJ, Series A, no.22, p. 13; Corfu Channel case, I.C.J. (09/04/1949), p. 24. See also: Japan - Taxation on alcoholic drinks, Report of the WTO Appellate Body AB-1992-2, WT/DS8/AB/R,WT/DS10/AB/R \& WT/DS11/AB/R [04/10/1996], p. 16; European Union - Custom Classification of Frozen Boneless Chicken Cuts, Report of the WTO Appellate Body AB-2005-5, WT/DS269/AB/R, WT/DS286/AB/R [12/09/2005], p. 92, para. 214.

76 See for example: Intra-Mercosur Investment Facilitation Protocol (07/04/2017), art. 24 (3); the 2015 Indian investment agreement model, art. 14.2. 
sibility clauses as an indicator of their good faith. Such provisions will indeed be a measure of the investors' clean hands and act as a benchmark of their legal protection. This assumption has already been echoed in the arbitral jurisprudence as debated in the next chapter.

\section{INVESTORS' CORPORATE SOCIAL BEHAVIOUR AS A BENCHMARK FOR THEIR PROTECTION AS PER THE ARBITRAL JURISPRUDENCE}

A mapping of the investment arbitral jurisprudence shows that investors' behaviour can be considered by arbitral tribunals to study the admissibility of their demand and the extent of their legal protection. This has been done even without the existence of specific provisions on investors' duties in investment agreements: some existing legal principles can be used to bring the issue of investors' duties in the debate. In that respect, investors' clean hands, in terms of corporate social behaviour, can act as a bar to their legal protection (3.1.) while their duty of transparency to the host State can help decide if they should be granted a legal protection (3.2.). If the investors' corporate social behaviour is ignored by arbitral tribunals, an unjust enrichment can then be arguably configured (3.3.).

\subsection{Investors' unclean hands as a bar to their legal protection}

According to the clean hands doctrine, a party to a dispute cannot ask for an equitable reparation to the other if it is itself in violation of a principle of equity ${ }^{77}$. The doctrine's existence has been recognised in international law $^{78}$ even if some doubts emerged as to its

77 Black's Law Dictionary, $9^{\text {th }}$ Edition, 2009, p.286; Sir G. Fitzmaurice, "The General Principles of International Law Considered from the Standpoint of the Rule of Law", Recueil des Cours, vol.92, 1957, p. 119. See also: Diversion of Water from the Meuse, P.C.I.J., Decision (28/06/1937), Individual Opinion of Judge Hudson, p.77; Military and Paramilitary activities in and against Nicaragua (Nicaragua v. United States of America), C.I.J., Decision (27/07/1986), Dissenting Opinion of Judge Schwebel, para. 269.

78 Report of the International Law Commission, Document A/60/10, 2005, p.108; Jean Salmon, "Des mains propres comme conditions de recevabilité des reclamations internationals", Annuaire français de droit international, vol.10, 1964, p. 232; Richard Kreindler, "Corruption in International Investment Arbitration: Jurisdiction and the Unclean Hands Doctrine", in, Kaj Hover, Annette Magnusson, Marie Ohrstrom (org.), Between East and West: Essay in the Honour of Elf Franke, application in matters of diplomatic protection ${ }^{79}$. Moreover, one arbitral tribunal has already held that the clean hands doctrine is not a general principle of law ${ }^{80}$.

In the Nikos Resources v. Bangladesh case, the arbitral tribunal considered that three conditions had to be fulfilled to support a 'clean hands' claim: (i) the violation justifying the invocation of the clean hands doctrine should still exist at the time of the claim; (ii) the solution requested by the claimant must put an end to such violation; (iii) there must exist a reciprocity in the obligations which constitute the object of the dispute ${ }^{81}$. These conditions are extracted from a Permanent Court of Arbitration award ${ }^{82}$ and the latter is itself inspired from an individual opinion of Judge Hudson in the Diversion of Water from the Meuse case ${ }^{83}$. In both of these cases, however, the legal dispute opposed two States. The third condition of reciprocity was therefore relevant in these cases but cannot be purely transposed to the reality of international investment law: a reciprocity of rights and obligations might exist in a contract signed between investor and State but is traditionally inexistent when it comes to international investment agreements - signed between the home and the host State. In the Meuse case, for example, the Netherlands claimed that some Belgian constructions on the Meuse river were contrary to a treaty signed between the two States; however, Netherlands' clean hands gravitated into the debate because it had itself undertaken other constructions along the same river. In this case, the claimant and the respondent, both States, had reciprocal obligations. Therefore,

Juris, 2010, pp. 317-318.

79 Report of the International Law Commission, Document A/60/10, 2005, pp.108-112; Patrick Dumbery, Gabrielle DumasAubin, "How to Impose Human Rights Obligations on Corporations Under Investment Treaties?", Yearbook of International Investment Law and Policy, vol.4, 2012, pp. 589-591; Aleksandr Shapovalov, "Should a Requirement of "Clean Hands" be a Prerequisite to the Exercise of Diplomatic Protection? Human Rights Implications of the International Law Commission's Debate", American University International Law Review, vol.20, 2005, pp. 829-866; Eric de Bradandere, "Human Rights Considerations in International Investment Arbitration", in, Malgosia Fitzmaurice and Panos Merkouris, The Interpretation and Application of the European Convention of Human Rights: Legal and Practical Implications, Leiden/Boston, Martinus Nijhoff Publishers, 2012, pp. 183-215.

80 Yukos Universal Limited (Isle of Man) $v$. The Russian Federation, UNCITRAL, PCA Case No. AA 227, Award (18/07/2014), para. 1363. 81 Niko Resources v. Bangladesh, ICSID no. ARB/10/11, Decision on Jurisdiction (19/08/2013), para 481.

82 Guyana v. Suriname, PCA, Award (17/09/2007), paras.417-422. 83 Diversion of Water from the Meuse, P.C.I.J., Decision (28/06/1937), Individual Opinion of Judge Hudson, p. 77. 
the conditions retrieved from the Guyana v. Suriname or from the Meuse case do not constitute an appropriate analogy. The first condition - the continuous violation — is similarly debatable. Indeed, in international investment law, an investor can have a socially irresponsible behaviour while constituting and establishing its activities but not necessarily afterwards; this means that such a behaviour might not prevail at the time of an arbitral procedure but it did exist upstream.

This said, even if a direct transposition of the aforementioned conditions in international investment law is not very convincing, it would be egregious to consider that a notorious social misconduct of an investor in no way affects his capacity to benefit from the shield of an investment agreement ${ }^{84}$. It will be argued hereinafter ${ }^{85}$ that condoning such conducts might configure an unjust enrichment. Examining the investors' conduct prior to measure the extent of their due protection is an issue which is not disregarded by arbitral tribunals. In other words, the clean hands doctrine or its inflections are used as a measure of investors' corporate social behaviour. The latter can prove relevant for an analysis of the investors' claims at two levels, both of which will be discussed infra: as a bar to jurisdiction and as bar to claims on the merits ${ }^{86}$.

In the Metal-Tech case, the investment had been made on the basis of an original act of corruption: the company bribed members of the host State's - Uzbekistan - government. The arbitral tribunal had to examine the legality of a joint-venture liquidation under the Israel-Uzbekistan bilateral investment agreement. On the basis of how the company constituted its investment, the arbitral tribunal stated that it lacked jurisdiction over the matter, the claims being "barred as a result of corruption" $"$. The same tribunal further noted:

"The Tribunal found that the rights of the investor against the host State, including the right of access to arbitration, could not be protected because the investment was tainted by illegal ac-

84 In a similar sense, see: Inceysa Vallisoletaba v. El Salvador, ICSID Case No. ARB/03/26, Award (02/08/2006), para. 248.

85 See section 2.3 .

86 Gustav F W Hamester GmbH \& Co KG v. Ghana, ICSID Case No. ARB/07/24, Award (18/06/2010), para. 127; Zachary Douglas, "The Plea of Illegality in Investment Treaty Arbitration", ICSID Review, Vol. 29, No. 1, 2014, pp.166-167; Jorge Viñuales, "Invest Diligence in Investment Arbitration: Sources and Arguments", ICSID Review, vol.32, $\mathrm{n}^{\circ} .22017$, p. 355 et eq.

87 Metal-Tech Ltd. v. Uzbekistan, ICSDI No. ARB/10/3, Award (04/10/2013), para. 389. tivities, specifically corruption. The law is clear - and rightly so - that in such a situation the investor is deprived of protection and, consequently, the host State avoids any potential liability" ${ }^{88}$.

Interestingly, the arbitral tribunal used the so-called "red flags" as indicators of acts of corruption". "Red flags" are indicators of practices of corruption which are referred to in reports on business ethics. The Metal-Tech tribunal used the Woolf report called Committee Report on Business Ethics, Global Companies and the Defence Industry: Ethical Business Conduct in Bae Systems Plc - The Way Forward ${ }^{\text {p0 }}$ to help characterise the corruption practice. Such practice was also contrary to the domestic laws of Uzbekistan on bribery. Access to arbitration is, in this sense, not an open-door policy and the investor is accountable for its actions. In the Inceysa v. El Salvador case, a Spanish company had obtained a concession contract for a service of vehicle inspection by misrepresenting, amongst others, its financial status and its technical competences. A dispute between investor and State was brought before an ICSID tribunal. The latter acknowledged that any given investment had to be made in accordance with the prevailing local laws as well as with what it coined as international public policy. Consequently, in the tribunals words, if it declared "itself competent to hear the disputes between the parties, it would completely ignore the fact that, above any claim of an investor, there is a meta-positive provision that prohibits attributing effects to an act done illegally"' ${ }^{\prime \prime}$. In the direct line of what the clean hands doctrine commands, the tribunal pointed out that "[n] o legal system based on rational grounds allows the party that committed a chain of clearly illegal acts to benefit from them" ${ }^{\prime 2}$. In light of this principle, the tribunal declined its jurisdiction: the investor's claim was barred ${ }^{93}$.

As per a similar logic, in other cases where the deba-

88 Metal-Tech Ltd. v. Uz̧ekistan, ICSDI No. ARB/10/3, Award (04/10/2013), para. 422.

89 Metal-Tech Ltd. v. Uzbekistan, ICSDI No. ARB/10/3, Award (04/10/2013), para. 293.

90 Woolf Committee, Committee Report on Business Ethics, Global Companies and the Defence Industry: Ethical Business Conduct in Bae Systems Plc - The Way Forward, May 2008, p.26 [available at: https:// www.icaew.com/-/media/corporate/files/technical/ethics/woolfreport-2008.ashx].

91 Inceysa Vallisoletaba v. El Salvador, ICSID Case No. ARB/03/26, Award (02/08/2006), para. 248.

92 Inceysa Vallisoletaba v. El Salvador, ICSID Case No. ARB/03/26, Award (02/08/2006), para. 244.

93 Inceysa Vallisoletaba v. El Salvador, ICSID Case No. ARB/03/26, Award (02/08/2006), para. 339. In a similar sense, see: Europe Cement Investment and Trade S.A. v. Republic of Turkey, ICSID Case $\mathrm{N}^{\circ}$. $\mathrm{ARB}(\mathrm{AF}) / 07 / 2$, Award (13/08/2009). 
te was on the merits and no longer on jurisdiction, the investors were not granted legal protection when there was enough evidence of corporate social misbehaviour. In the World Duty Free v. Kenya case, a British company was charged of building and operating duty-free shops of the airports of Nairobi and Mombasa. However, the contract with the host State was made possible only in counterpart of a bribe of two million dollars paid to the Kenyan President. Hence, the company's activity started with an act of corruption. The latter had infringed Kenyan law and characterised a socially irresponsible conduct. The case was brought to arbitration on a claim of expropriation made by the investor. The arbitral tribunal stated that an illegal conduct of a company barred the latter in lodging a claim against an illegal action of the other contracting party ${ }^{94}$. The tribunal referred to the ex turpi causa non oritur actio principle ${ }^{95}$, that is, 'from a dishonourable cause an action will not arise'. Admitting the claimants request would be contrary to what the tribunal coined as transnational public policy ${ }^{96}$. Analysing an investor's fraudulent conduct in the Plama case, the arbitral tribunal highlighted:

"The Tribunal is of the view that granting the ECT's? protections to Claimants investments would be contrary to the principle nemo auditor propriam allegans [...]. It would also be contrary to the basic notion of international public policy — that a contract obtained by wrongful means (fraudulent misrepresentation) should not be enforced by a tribunal. ${ }^{98}$

That a fraudulent ${ }^{99}$ activity or investment cannot be protected by an investment agreement is a general principle that has built into international investment law and arbitration ${ }^{100}$; investors have the duty to be aware

94 World Duty Free v. Kenya, ICSID Case No. ARB/00/7, Award (04/10/2006), para. 179.

95 World Duty Free v. Kenya, ICSID Case No. ARB/00/7, Award (04/10/2006), para. 179.

96 World Duty Free v. Kenya, ICSID Case No. ARB/00/7, Award (04/10/2006), para. 157. See also: R. Zachary Torres-Fowler, "Undermining ICSDI: How the Global Antibribery Regime Impairs Investor-State Arbitration", Virginia Journal of International Law, vol.52, no.4, 2012, p. 988.

97 Energy Charter Treaty.

98 Plama Consortium Ltd. v. Bulgaria, ICSID Case No. ARB/03/24, Award (27/08/2008), para. 143.

99 The fraud must conspicuously be duly evidenced. See: The Rompetrol Group N.V. v. Romania, ICSID Case No. ARB/06/3, Award (06/05/2013), paras. 182.

100 David Minnotte and Robert Lewis v. Poland, ICSID Case No. ARB(AF)/10/1, Award (16/05/2014), para. 131; Abaclat and others v. Argentine Republic, (ICSID Case No. ARB/07/5, Decision on Jurisdiction and Admissibility (04/08/2011), para. 648. of this principle ${ }^{101}$. Consequently, even a proven violation of an investment agreement by State might bar an investor's claim in case of corporate social misconduct. For instance, in the Hesham Talaat M. Al-Warraq case, the arbitral tribunal found that the Host State, Indonesia, had infringed the Agreement on Promotion, Protection and Guarantee of Investments among Member States of the Organisation of the Islamic Conference's provision on fair and equitable treatment. However, this was matched with the Saudi investor's acts related to corruption and money laundering in the banking sector. The tribunal perpended the company's behaviour and concluded that the clean hands doctrine applied to the case. The doctrine was used to uphold the content of article 9 of the agreement which provides that the investors must "refrain from all acts that may disturb public order or morals or that may be prejudicial to the public interest" and that " $\mathrm{h}] \mathrm{h}$ is also to refrain from exercising restrictive practices and from trying to achieve gains through unlawful means" 102 . Resultantly, despite the agreement's violation by Indonesia, the investor's claim was barred ${ }^{103}$.

The distribution of rights and duties between investors and States does not abide to a Manichean logic; the Host States are not completely exonerated of their responsibility because of the corporate social misconduct of investors. In matters of corruption, for example, the illegal act is necessarily materialised by the participation of a State's representative. The latter — President, members of the Government — was clearly identified in the abovementioned cases; thus, a claim's dismissal by an arbitral tribunal often implies that there has been a reprehensible conduct of both parties, investor and State. If so, one tribunal has already decided that the Parties should share the costs of the arbitral procedu$\mathrm{re}^{104}$. If not, that is in the absence of State collusion, another tribunal considered that the costs had to be supported by the sole investor ${ }^{105}$.

The applicability of the clean hands hypothesis is,

101 Fraport AG Frankfurt Airport Services Worldwide v. The Philippines, ICSID Case No. ARB/03/25, Award (16/08/2007), para. 402.

102 Agreement on Promotion, Protection and Guarantee of Investments among Member States of the Organisation of the Islamic Conference (05/06/1981), art.9.

103 Hesham Talaat M. Al-Warraq v. Indonesia, UNCITRAL, Award $(15 / 12 / 2014)$, paras. 647-648. For a critical analysis of this case, see Hervé Ascensio's article in this same issue.

104 Metal-Tech Ltd. v. Uzbekistan, ICSDI No. ARB/10/3, Award (04/10/2013), paras. 422-423.

105 Inceysa Vallisoletaba v. El Salvador, ICSID Case $\mathrm{N}^{\circ}$. ARB/03/26, Award (02/08/2006), para. 338. 
as such, at least tested in the arbitral jurisprudence. It is possible to postulate a legal articulation between investors' duties and the clean hands doctrine in the sense that corporate misconduct implies unclean hands and the latter acts as a bar to investors' protection. If companies have a legitimate expectation that the State will act coherently, consistently and in full transparency ${ }^{106}$, it can conversely be legitimately expected that investors demonstrate practices of corporate social responsibility or the inexistence of corporate social misconduct in order to plead the applicability of a given investment agreement.

Besides the clean hands doctrine, the arbitral jurisprudence also reveals that investors have a duty of transparency vis-à-vis their host States: infringing this duty might boil down to a fraudulent manoeuvre.

\subsection{Investors' duty of transparency as a measure of their legal protection}

Before establishing their activities, investors normally have to provide basic information to the host State, namely on their financial situation or on their technical capacities. In this sense, there is an expectation that they act transparently towards the State. Some new agreements provide that the investors have a duty to inform the host State about their corporate governance history and agenda ${ }^{107}$. Nevertheless, some investments have sometimes been successfully established on the basis of erroneous information communicated to the host State. This is even more abusive when done in the context of developing States which do not always have all the technical means to double-check the communicated information ${ }^{108}$, without mentioning that the com-

106 See generally: Michele Potestà, "Legitimate Expectations in Investment Treaty Law: Understanding the Roots and the Limits of a Controversial Concept", ICSID Review, vol. 28, 2014, pp. 88-122; Rudolf Dolzer, "Fair and Equitable Treatment: Today's Contour", Santa Clara Journal of International Law, vol.12, 2014, p. 7-33; Elizabeth Snodgrass, "Protecting Investors' Legitimate Expectations: Recognizing and Delimiting a General Principle", ICSID Review, vol.21, 2006, pp. 1-58; Nitish Monebhurrun, "Gold Reserve Inc. v. Bolivarian Republic of Venezuela - Enshrining Legitimate Expectations as a General Principle of International Law?", Journal of International Arbitration vol.32, n. 5, 2015, pp. 551-562.

107 Bilateral Investment Agreement between Morocco and Nigeria $(03 / 12 / 2016)$, art.21 (1).

108 Peter Muchlinski, "Caveat Investor? The Relevance of the Conduct of the Investor under the Fair and Equitable Treatment Standard", International and Comparative Law Quarterly, vol.55, 2006, p. 538. panies' good faith is, in any case, presumed.

In the Azinian v. Mexico case, the arbitral tribunal noted that the investment had been made possible only because the (American) investor had voluntarily exaggerated its intrinsic technical experience and financial means in the waste management sector ${ }^{109}$; there was a will to impress but at the same time to mislead the State through false representations and unfeasible promises ${ }^{110}$. The investor invoked a curious argument as a means of defence: it argued that the host State should not have believed its overtly optimistic and unreasonable promises; the argument did not convince the tribunal ${ }^{111}$. A similar situation arose in the already mentioned Inceysa case: the investment was accepted by the host State, El Salvador, after having received fraudulent information from the investor, erroneous information on financial and budgetary matters, on the competence of employees, dissimulation of technical competences and of the content of its real experience in the field of vehicle inspection ${ }^{112}$. The arbitral tribunal found that such dissimulation and that the deceptive information constituted a forgery which removed the applicable investment agreement's protective umbrella from above the investor. True, the host State must not passively believe all the fabulous promises made by the investor and must deploy all reasonable means to ascertain the representations' veracity; however, the State's diligence may vary as per their available resources, which in turn depends on their level of development.

These cases can inductively trace the contours of a duty of transparency, the latter acting as a means to construe investment agreements so as to assess the outreach of the standards of treatment and protection. The investors' duty of transparency covers a wider spectrum of concern as it has an indirect impact on the host State's population. The investor is paid by the State as there is an expectation that the financed activity be beneficial to its society and population. There is therefore an opportunity cost embedded in such investment as the value paid to the investor excludes other potential investments which could have been made to benefit the

109 Robert Azinian, Kenneth Davitian and Ellen Bacca v. Mexico, ICSID Case No. ARB (AF)/97/2, Award (01/11/1999), paras. 29-33. 110 Robert Azinian, Kenneth Davitian and Ellen Bacca v. Mexico, ICSID Case No. ARB (AF)/97/2, Award (01/11/1999), para. 107. 111 Robert Azinian, Kenneth Davitian and Ellen Bacca v. Mexico, ICSID Case No. ARB (AF)/97/2, Award (01/11/1999), para. 108. 112 Inceysa Vallisoletaba v. El Salvador, ICSID Case $\mathrm{N}^{\circ}$. ARB/03/26, Award (02/08/2006), para. 236. 
same population. When an investment is fraudulently constituted through misrepresentations of the investor, the opportunity cost is materialised given that there is an inefficient allocation of resources to the detriment of the local population. For this reason, the duty of information goes beyond the small sphere of the arbitral procedure and relate, more widely to the investor's corporate social responsibility.

If this duty of transparency is not legally considered and if, similarly, the investors' unclean hands are ignored, they would, in other words, be deriving a benefit — its investment and profits — from fraudulent acts or from practices of corruption. Said sardonically, their corporate social misconduct would in a certain way be rewarded. To ignore investors' duties would be tantamount to an unjust enrichment ${ }^{113}$.

\subsection{The Constitution of an Unjust Enrichment in case of the non-recognition of investors' duties}

Unjust enrichment has been considered as a general principle of $\operatorname{law}^{114}$. An undue enrichment to the detri-

113 American Manufacturing and Trading v. Zaire, ICSID Case N $\mathrm{N}^{\mathrm{.}}$ ARB/93/1, Award (21/02/1997), para. 7.15.

114 Benjamin R. Isaiah v. Bank. Mella, Iran-USA Claims Tribunal, Case No. 219, Award Nº. 35-219-2 (30/03/1983), Iran-USA Claims Tribunal Reports, vol.2, p. 236; Sea-Land Services Inc. v. Iran, Iran-USA Claims Tribunal, Case no.33, Award n. 135-33-1 (20/06/1984), Iran-USA Claims Tribunal Reports, vol.6, 1984, p. 169; Saluka Investments v. Czech Republic, UNICITRAL, Partial Award (17/03/2006), para. 449; Inceysa Vallisoletaba v. El Salvador, ICSID Case No. ARB/03/26, Award (02/08/2006), para. 254; Ambatielos Case (Greece v. United Kingdom and Northern Ireland), Dissenting Opinion of Professor Spiropoulos (06/03/1956), Recueil des sentences arbitrales des Nations Unies, vol. XII, p. 129. See also: Lena Goldfields Ltd. v. USSR, Award (03/09/1930), para. 25.

For the legal literature, see: Kit Barker, « Understanding the Unjust Enrichment Principle in Private Law : A Study of the Concept and its Reasons ", in, J.W. Neyers, M. Mcinnes, S.G.A. Pittel [org.], Understanding Unjust Enrichment, Portland, Hart Publishing, 2004, p. 82; Detlev C. Dicke, "Unjust enrichment and compensation", in, Detlev C. Dicke [dir.], Foreign Investment in the Present and a New International Economic Order, Fribourg, University Press Fribourg Switzerland, 1987, p. 269; Brice Dickson, «Unjust Enrichment Claims : A Comparative Overview », Cambridge Law Journal, vol. 54, no.1, 1995, pp. 100-126; Christoph Schreuer, Christina Binder, "Unjust Enrichment », The Max Planck Encyclopedia of Public International Law, Oxford University Press, 2007, para. 10, online edition [available at: www.mpepil. com]; Lord Mcnair, «The General Principles of Law Recognised by Civilised Nations ", British Yearbook of International Law, vol.33, 1957, p. 11; Ana Vohryzek, «Unjust Enrichment Unjustly Ignored: Opportunities and Pitfalls in Bringing Unjust Enrichment Claims under ICSID ", Loyola of Los Angeles International and Comparative Law Review, vol.3, 2009, p. 503. ment of a party must be restored from the perspective of commutative justice ${ }^{115}$. The Iran-USA Claims tribunal enlightened the principle's content and its case law often inspires modern arbitral tribunals ${ }^{116}$. In the Sea-land Services v. Iran case, unjust enrichment was defined as such:

"There must have been an enrichment of one party to the detriment of the other, and both must arise as a consequence of the same act or event. There must be no justification for the enrichment, and no contractual or other remedy available to the injured party whereby he might seek compensation from the party enriched ${ }^{17}$ ".

Five conditions must be fulfilled: 1) the enrichment of one party; 2) the impoverishment of the other party; 3) a causal relationship between the enrichment and the impoverishment; 4) an unjustified enrichment; 5) the absence of a means of redress for the impoverished $\operatorname{party}^{118}$.

The enrichment could be realised in two ways. Firstly, the profits made by a company having won a bid or a contract through fraud or acts of corruption could be tantamount to an unjust enrichment; these profits would never have never been made without the original illegality. Secondly, reparations ordered by a tribunal and paid by a State to a company having had a corporate social misconduct during its investment could also be equivalent to an unjust enrichment. In a Repsol v. Ecuador case, the defendant State argued before an Annulment Committee that it had a moral duty to annul an award rendered by an arbitral tribunal so as not to unjustly enrich the foreign company ${ }^{119}$. The principle of unjust enrichment appears as an objective means of balance

115 Kit Barker, "Understanding the Unjust Enrichment Principle in Private Law : A Study of the Concept and its Reasons ", in, J.W. Neyers, M. Mcinnes, S.G.A. Pittel [org.], Understanding Unjust Enrichment, Portland, Hart Publishing, 2004, p. 97; Daniel Patrick O'Connell, "Unjust Enrichment", The American Journal of Comparative Law, vol.V, 1956, p. 4.

116 Saluka Investments v. Czech Republic, UNICITRAL, Partial Award (17/03/2006), para. 449; Aqurix v. Argentina, ICSID Case No. ARB/01/12, Award (14/07/2006), para.437.

117 Sea-Land Services Inc. v. Iran, Iran-USA Claims Tribunal, Case $\mathrm{n}^{\circ} .33$, Award no. 135-33-1 (20/06/1984), Iran-US A Claims Tribunal Reports, vol.6, 1984, p. 169.

118 Christoph Schreuer, Christina Binder, «Unjust Enrichment », The Max Planck Encyclopedia of Public International Law, Oxford University Press, 2007, paras. 1-2, online edition [available at : www. mpepil.com]

119 Repsol YPF Ecuador S.A. v. Ecuador, ICSID Case No. ARB/01/10, Decision on Annulment (28/01/2007) para. 25. 
between the distribution of rights and duties of investors and States ${ }^{120}$ : it helps grasp the big picture of their relationship.

The unjust enrichment argument was accepted by the arbitral tribunal in Inceysa. It is worth recalling that the investor's establishment in El Salvador had been successful only because of various misinformation and misrepresentations. The arbitral tribunal decided that the activity, by way of its constitution, was not an investment and refused to hear the claims on the merits. Accepting the investor's request would, for the tribunal, imply creating favourable conditions for an unjust enrichment:

"Applying the principle [of unjust enrichment] to the case at hand, we note that Inceysa resorted to frand to obtain a benefit that it would not have otherwise obtained. Thus, through actions that violate the legal principles [of unjust enrichment], Inceysa tried to enrich itself, signing an administrative contract with $M A R N$, which, without any doubt, would produce considerable profit for it. (...). The clear evidence that proves the violations listed in chapter IV of this award leads this Tribunal to decide that an interpretation that would grant BIT protection to Inceysa's illegal investment would favor its unlawful enrichment, which no tribunal constituted according to the Agreement can do. ${ }^{121}$ "

Tentatively, the five conditions mentioned above find application here. The enrichment is related to the profits derived from an illegally constituted activity. This enrichment is due to payments made by the State and by its population; the latter is consequently impoverished. The causal relationship is crystalized given that the enrichment of one party results from the impoverishment of the other (the State and one of the component of the State, its population). The enrichment is unjust because of the illegality and corporate misconduct characterising the investor's activity. The impoverished State does not really have a means of redress against the investor in international law.

Just like the company's clean hands or duty of transparency, the principle of unjust enrichment appears as another legal strategy to block investor's abusive claims. Most importantly, the combination of these duties is useful to raise investors' awareness about the legal consequences of corporate social misconduct, that is, to in-

120 ENRON Corp. Ponderosa Assets L.P. v. Argentina, ICSID Case No. ARB/01/3, Award (22/07/2007), para. 214.

121 Inceysa Vallisoletaba v. El Salvador, ICSID Case No. ARB/03/26, Award (02/08/2006), paras. 255-256. form that their legal protection under investment agreements depends on their corporate social responsibility.

\section{Concluding Remarks}

This article had for main aim tracing, while categorising, a trend of investors' duties in international investment law. If the legal landscape is still patchy on this question, perusing the spheres of investment agreements and of the arbitral jurisprudence has shown permeability for corporate social responsibility in a manner that is conducive to its articulation with the traditional standards of treatment and protection of investments. This articulation revealed that investors' duties are gradually acquiring a legal purpose, if not a consensual acceptance. The inclusion of these duties in this law field plays a double role: that of an adjuvant to champion the creation of a corporate social responsibility culture and that of an interpretative instrument used to objectively assess the extent of investors' protection under investment agreements.

\section{References}

\section{Agreements and Official Documents}

Statute $n^{\circ}$ 2017-399 on the Duty of Diligence of parent companies (in French, loi relative au devoir de vigilance des sociétés mères et des entreprises donneuses d'ordre) [27/03/2017] (available at: https://www.legifrance.gouv.fr/eli/ loi/2017/3/27/2017-399/jo/texte).

Human Rights Council, "Report on the second session of the open-ended intergovernmental working group on transnational corporations and other business enterprises with respect to human rights", Resolution A/ HRC/34/47 [04/01/2017] (Special rapporteur: María Fernanda Espinosa).

Working Group on the issue of human rights and transnational corporations and other business enterprises (Human Rights Council), Report on Promotion and protection of human rights: buman rights questions, including alternative approaches for improving the effective enjoyment of buman rights and fundamental freedoms, Document A/72/162 [18/07/2017]. 
Intra-Mercosur Investment Facilitation Protocol (07/04/2017).

Bilateral Investment Agreement between Morocco and Nigeria (03/12/2016).

Bilateral Investment Agreement between Iran and Slovakia (19/01/2016).

Bilateral Investment Agreement between Argentina and Qatar (06/11/2016).

Agreement Between Canada and Mongolia for the Promotion and Protection of Investments (08/09/2016).

Investment agreement between the Hong Kong Special Administrative Region of the People's Republic of China and Chile (18/11/2016).

Free-Trade Agreement signed between Canada and The European Union (30/10/2016).

The Trans-Pacific Partnership (04/02/2016).

Investment Agreement between the Hong Kong Special Administrative Region of the People's Republic of China and Chile (18/11/2016).

Free-Trade Agreement between Chile and Uruguay (04/10/2016).

economic and commercial agreement between Brazil and Peru (29/04/2016).

Investment Agreement between Singapore and Nigeria (04/11/2016).

Free-Trade Agreement between the European Union and the SADC (10/06/2016).

Free-Trade Agreement between the European Union and Kazakhstan (21/12/2015).

Brazil-Chile ACFI (24/11/2015).

Brazil-Colombia ACFI (09/10/2015).

Brazil-Anglo ACFI (01/04/2015).

Brazil-Mozambique ACFI (30/03/2015).

Brazil-Mexico ACFI (26/05/2015).

Brazil-Malawi ACFI (25/06/2015).

Bilateral Investment Agreement between Canada and Guinea (27/05/2015).

Bilateral Investment Agreement between Canada and Burkina Faso (20/04/2015).

Bilateral Investment Agreement between Canada and
Cameroon (03/03/2014).

Free-Trade Agreement signed between Canada and South Korea (22/05/2014).

Bilateral Investment Agreement between Canada and Ivory Coast (30/11/2014).

Free-Trade Agreement between the European Union and Georgia (27/06/2014).

Free-Trade Agreement between the European Union and Moldavia (27/06/2014).

Free-Trade Agreement between the European Union and Ukraine (27/06/2014).

Bilateral Investment Agreement between Canada and Mali (28/11/2014).

Bilateral Investment Agreement between Canada and Nigeria (06/05/2014).

Bilateral Investment Agreement between Canada and Senegal $(27 / 11 / 2014)$.

Bilateral Investment Agreement between Canada and Serbia (01/09/2014).

Bilateral investment agreement between France and Colombia (10/07/2014).

Bilateral Investment Agreement between Canada and Benin (09/01/2013).

Free-Trade Agreement signed between Canada and Honduras (05/11/2013).

Free-trade agreements between Colombia and Panama (20/09/2013).

Free-trade agreements between Colombia and Costa Rica (22/05/2013).

Bilateral investment agreement signed between the Netherlands and United Arab Emirates (26/11/2013).

Free-trade agreements between Colombia and the European Union and Peru (26/06/2012).

Free-Trade Agreement signed between Canada and Panama $(14 / 05 / 2010)$.

Free-Trade Agreement between the European Union and South Korea (06/10/2010).

Agreement Concerning Annual Reports on Human Rights and Free Trade Between Canada and the Republic of Colombia (27/05/2010). 
Human Rights Council, "Elaboration of an international legally binding instrument on transnational corporations and other business enterprises with respect to human rights", Draft Resolution A/HRC/26/L.22/ Rev.1 [25/06/2014].

Human Rights Council, "Human rights and transnational corporations and other business enterprises", Draft resolution A/HRC/26/L.1 [23/06/2014].

United Nations, "Guiding Principles on Business and Human Rights. Implementing the United Nations "Protect, Respect and Remedy" Framework", New York and Geneva, United Nations [2011].

United Nations Environmental Program, Corporate Social Responsibility and Regional Trade and Investment Agreements, UNEP, 2011.

Free-Trade Agreement signed between Canada and Colombia $(21 / 11 / 2008)$.

Free-Trade Agreement signed between Canada and Peru (29/05/2008).

International Labour Organization Declaration on Fundamental Principles and Rights at Work [18/06/1998] [available at: http://www.ilo.org/wcmsp5/groups/ public/---ed_norm/---declaration/documents/publication/wcms_467653.pdf]

Global Compact, adopted on the $26^{\text {th }}$ July 2000 (available at: https://www.unglobalcompact.org/what-is-gc/ mission/principles).

Agreement on Promotion, Protection and Guarantee of Investments among Member States of the Organisation of the Islamic Conference (05/06/1981).

\section{Cases}

Yaiguaje v. Chevron Corporation, 2017 ONSC 135 (CanLII) [20/01/2017].

International Monsanto Tribunal, Advisory Opinion (18/04/2017) [available at: http:// en.monsantotribunal. org/upload/asset_cache/189791450.pdf].

Mamidoil Jetoil Greek Petroleum Products Société S.A. v. Albania, ICSID n ARB/11/24, Award (30/03/2015).

Jagarnath Sabu, et al., v. Union Carbide Corporation and Madhya Pradesh State, United States District Court Southern District of New York, Case nº 07 Civ. 2156 [30/07/2014].
Yukos Universal Limited (Isle of Man) v. The Russian Federation, UNCITRAL, PCA Case N${ }^{\circ}$. AA 227, Award (18/07/2014).

Hesham Talaat M. Al-Warraq v. Indonesia, UNCITRAL, Award (15/12/2014).

David Minnotte and Robert Lewis v. Poland, ICSID Case No. ARB(AF)/10/1, Award (16/05/2014).

Niko Resources v. Bangladesh, ICSID no. ARB/10/11, Decision on Jurisdiction (19/08/2013).

The Rompetrol Group N.V. v. Romania, ICSID Case No. ARB/06/3, Award (06/05/2013).

SAUR International S.A. v. Argentina, ICSID n ${ }^{\circ} 04 / 4$, Decision on Jurisdiction and Liability (6/06/2012).

Abaclat and others v. Argentine Republic, (ICSID Case $\mathrm{N}^{\circ}$. ARB $/ 07 / 5$, Decision on Jurisdiction and Admissibility (04/08/2011).

Gustav F W Hamester GmbH \& Co KG v. Ghana, ICSID $n^{\circ}$ ARB/07/24, Award (18/06/2010).

Metal-Tech Ltd. v. Uz̧ekistan, ICSDI No. ARB/10/3, Award (04/10/2013).

Europe Cement Investment and Trade S.A. v. Republic of Turkey, ICSID Case $\mathrm{N}^{\circ}$. $\mathrm{ARB}(\mathrm{AF}) / 07 / 2$, Award $(13 / 08 / 2009)$.

Plama Consortium Ltd. v. Bulgaria, ICSID Case $\mathrm{N}^{\circ}$. ARB/03/24, Award (27/08/2008).

Guyana v. Suriname, PCA, Award (17/09/2007).

Fraport AG Frankfurt Airport Services Worldwide v. The Philippines, ICSID Case $\mathrm{N}^{\circ}$. ARB/03/25, Award (16/08/2007).

Inceysa Vallisoletaba v. El Salvador, ICSID Case $\mathrm{N}^{\circ}$. ARB/03/26, Award (02/08/2006).

World Duty Free v. Kenya, ICSID Case No. ARB/00/7, Award (04/10/2006).

European Union - Custom Classification of Frozen Boneless Chicken Cuts, Report of the WTO Appellate Body AB2005-5, WT/DS269/AB/R, WT/DS286/AB/R [12/09/2005].

Sucumbios Provincial Court of Justice [Sole Chamber], Lawsuit N. 2003-0002 [Reporting Judge: Nícolas Zambrano Lozada].

Robert Azinian, Kenneth Davitian and Ellen Bacca v. Mexico, ICSID Case No. ARB (AF)/97/2, Award (01/11/1999). 
American Manufacturing and Trading v. Zaire, ICSID Case No. ARB/93/1, Award (21/02/1997).

Japan - Taxation on alcoholic drinks, Report of the WTO Appellate Body AB-1992-2, WT/DS8/AB/R,WT/ DS10/AB/R \& WT/DS11/AB/R [04/10/1996].

Union of India v. Union Carbide, United States Court of Appeal, Second Circuit, 809 F.2d 195 [14/01/1987].

Military and Paramilitary activities in and against Nicaragua (Nicaragua v. United States of America), C.I.J., Decision (27/07/1986).

Free Zones of Upper Savoy and the District of Gex, PCIJ, Series A, no.22, p. 13; Corfu Channel case, I.C.J. (09/04/1949).

Diversion of Water from the Meuse, P.C.I.J., Decision (28/06/1937).

Lena Goldfields Ltd. v. USSR, Award (03/09/1930).

Competence of the ILO to Regulate Incidentally the Personal Work of the Employer, PCIJ, Advisory Opinion, Series B, no.13 (23/07/1926).

\section{Doctrine}

Aleksandr Shapovalov, "Should a Requirement of "Clean Hands" be a Prerequisite to the Exercise of Diplomatic Protection? Human Rights Implications of the International Law Commission's Debate", American University International Law Review, vol.20, 2005.

Amiram Gill, "Corporate Governance as Social Responsibility: A Research Agenda", Berkley Journal of International Law, vol.26, nº.2, 2008.

Anna Beckers, Enforcing Corporate Social Responsiility Codes. On Global Self-Regulationa and National Private Law, Oxford, Hart Publishing, 2015.

Black's Law Dictionary, 9 ${ }^{\text {th }}$ Edition, 2009.

Brian Roach, "Corporate Power in a Global World", Global Development and Environment Institute Working Paper, 2007, p. 5 [available at: http://www.ase.tufts.edu/ gdae/education_materials/modules/Corporate_Power_in_a_Global_Economy.pdf].

Corinne Gendron, "Penser l'acceptabilité sociale : audelà de l'intérêt, les valeurs »(2014), Revne internationale Communication sociale et publique, vol.11, 2014.

Delphine Couveinhes-Matsumoto, Les droits des peoples autochtones et l'exploitation des ressoucres naturelles en Améri- que latine, Paris, L'Harmattan, 2016.

Elizabeth Snodgrass, 'Protecting Investors' Legitimate Expectations: Recognizing and Delimiting a General Principle", ICSID Review, vol.21, 2006.

Eric David, Gabrielle Lefèvre, Juger les multinationales. Droits humains bafoués, ressources pillées, impunité organisée, Bruxelles, Louvain, 2015.

Erik Assadourian, "Transforming Corporations", in, Linda Starke (org.), The State of the World 2006. A Worldwatch Institute Report on Progress Toward a Sustainable Society, London, WW. Norton and Company, 2006.

Eric de Bradandere, "Human Rights Considerations in International Investment Arbitration", in, Malgosia Fitzmaurice and Panos Merkouris, The Interpretation and Application of the European Convention of Human Rights: Legal and Practical Implications, Leiden/Boston, Martinus Nijhoff Publishers, 2012.

Fabio Morosini and Michelle Ratton Sanchez Badin, 'The Brazilian Agreement on Cooperation and Facilitation of Investments (ACFI): A New Formula for International Investment Agreements?' Investment Treaty News (4 August 2015) https://www.iisd.org/ itn/2015/08/04/the-brazilian-agreement-on-cooperation-and-facilitation-of-investments-acfi-a-new-formula-for-international investment-agreements/.

Gilles Lhuilier, Le droit transnational, Paris, Dalloz, 2016.

Harwell Wells, «The Cycles of Corporate Social Responsibility: An Historical Retrospective for the Twenty-first Century", Kansas Law Riew, vol.51, 2002.

Hervé Ascensio, "Le pacte mondial et l'apparition d'une responsabilité internationale des entreprises", in, Laurence Boisson de Chazournes, Emmanuelle Mazuyer, Le Pacte mondial - 10 ans après. The Global Compact - 10 Years After, Bruxelles, Bruylant, 2011.

James Rochlin, "A golden opportunity lost: Canada's Human Rights Impact Assessment and the Free Trade Agreement with Colombia", The International Journal of Human Rights, vol.18, no.4/5, 2014.

Jean-Pascal Gond, Jacques Igalens, La responsabilité sociale de l'entreprise, Paris, PUF, 2008.

Jean Salmon, "Des mains propres comme conditions de recevabilité des reclamations internationals", Annuaire français de droit international, vol.10, 1964.

Jennifer Zerk, "Corporate Liability for Gross Human 
Rights Abuses. Towards a Fairer and More Effective System of Domestic Law Remedies", Report prepared for the Office of the UN High Commissioner for Human Rights, 2014.

Jorge Viñuales, "Invest Diligence in Investment Arbitration: Sources and Arguments", ICSID Review, vol.32, $\mathrm{n}^{\circ} .2,2017$.

Judith Kimerling, "Oil, Contact, and Conservation in the Amazon: Indigenous Huaorani, Chevron, and Yasuni", Colorado Journal of International Environmental Law and Policy, vol.24, $\mathrm{n}^{\circ} .1,2013$.

Kate Miles, The Origins of International Investment Law. Empire, Environment and the Safeguarding of Capital, Cambridge, Cambridge University Press, 2013.

Karl P. Sauvant, "The Negotiations of the United Nations Code of Conduct on Transnational Corporations Experience and Lessons Learned", Journal of World Investment and Trade, vol.16, 2015.

Kartsen Nowrot, "How to Include Environmental Protection, Human Rights and Sustainability in International Investment Law?", Journal of World Investment and Trade, vo.15, 2014.

Lilian Aponte Miranda, "The Hybrid State-Corporate Enterprise and Violations of Indigenous Land Rights: Theorizing Corporate Responsibility and Accountability under International Law", Lewis \& Clark Law Review, vol.135, 2007.

Manoela Carneiro Roland et al., Violation of Human Rights by Companies. The Case of the Açu Port, Juiz de Fora, HOMA-Human Rights and Business Centre, 2016.

Maria Júlia Gomes de Andrade et al., Inside the Vale of Mud: A Report on the Tailings Dam Collapse in Brazil, Rio de Janeiro, Justiça Global, 2016.

Marie-Ange Moreau, "Le devoir de vigilance", Droit social, no.10, October 2017.

Maxi Lyons, "A Case Study in Multinational Corporate Accountability: Ecuador's Indigenous Peoples Struggle for Redress", Denver Journal of International Law and Policy, vol.32, 2004.

Michael Wright, "Corporations and Human Rights. A Survey of the Scope and Patterns of Alleged Corporate Human Rights Abuse", Corporate Social Responsibility Initiative, working paper no.44, Cambridge MA: John F. Kennedy School of Government, Harvard University, 2008.
Michele Potestà, "Legitimate Expectations in Investment Treaty Law: Understanding the Roots and the Limits of a Controversial Concept", ICSID Review, vol. 28, 2014.

Milton Friedman, "The Social Responsibility of Business is to Increase Its Profits", The New York Times Magazine, 16 septembre 1970 [available at: http://wwwrohan.sdsu.edu/faculty/dunnweb/rprnts.friedman. dunn.pdf].

Mireille Delmas-Marty, Aux quatre vents du monde. Petit guide de navigation sur l'océan de la mondialisation, Paris, Seuil, 2016.

Muthucumaraswamy Sornarajah, "Mutations of NeoLiberalism in International Investment Law ", Trade Law and Development, vol.3, 2011.

Muthucumaraswamy Sornarajah, «Power and Justice: Third World Resistence in International Law », Singapore Yearbook of International Law, vol.10, 2006.

Nicolas Cuzacq, "Panorama en droit économique", in, Kathia Martin-Chenut, René de Quenaudon, La RSE saisie par le droit. Perspective interne et internationale, Paris, Pédone, 2016.

Nitish Monebhurrun, "Novelty in International Investment Law: The Brazilian Agreement on Cooperation and Facilitation of Investments as a Different International Investment Agreement Model", Journal of International Dispute Settlement, vol.8, 2017.

Nitish Monebhurrun, La fonction du développement dans le droit international des investissements, Paris, L'Harmattan, 2016.

Nitish Monebhurrun, "Gold Reserve Inc. v. Bolivarian Republic of Venezuela - Enshrining Legitimate Expectations as a General Principle of International Law?”, Journal of International Arbitration vol.32, nº. 5, 2015.

Noreena Hertz, The Silent Takeover. Global Capitalism and the Death of Democracy, London, Arrow, 2002.

OECD, "Fair and Equitable Treatment Standard in International Investment Law", OECD Working Papers on International Investment, 2004/03, OECD Publishing.

Olivier de Schutter, "Towards a New Treaty on Business and Human Rights", Business and Human Rights Journal, vol.1, no.1., 2015.

Patrick Juillard, "Le système actuel est-il déséquilibré en 
faveur de l'investisseur privé étranger et au détriment de l'État d'accueil ? ", in, Charles Leben (org.), Le contentieux arbitral transnational relatif à l'investissement. Nouveaux Développements, Paris, L.G.D.J., 2006.

Patrick Dumbery, Gabrielle Dumas-Aubin, "How to Impose Human Rights Obligations on Corporations Under Investment Treaties?", Yearbook of International Investment Law and Policy, vol.4, 2012.

Peter Muchlinski, "Caveat Investor? The Relevance of the Conduct of the Investor under the Fair and Equitable Treatment Standard", International and Comparative Law Quarterly, vol.55, 2006.

R. Zachary Torres-Fowler, "Undermining ICSDI: How the Global Antibribery Regime Impairs Investor-State Arbitration", Virginia Journal of International Law, vol.52, $\mathrm{n}^{\circ} .4,2012$.

Richard Kreindler, "Corruption in International Investment Arbitration: Jurisdiction and the Unclean Hands Doctrine", in, Kaj Hover, Annette Magnusson, Marie Ohrstrom (org.), Between East and West : Essay in the Honour of Elf Franke, Juris, 2010.

Rudolf Dolzer, "Fair and Equitable Treatment: Today's Contour", Santa Clara Journal of International Law, vol.12, 2014.

Rudolf Dolzer and Christoph Schreuer, Principles of International Investment Law, New York, Oxford University Press, 2009.
Sherpa, "Affaire Auchan/Rana Plaza : de nouvelles preuves de violations des droits des travailleurs dans les usines sous-traitantes du distributeur", Press Release (20/10/2015) [available at: https://www.asso-sherpa. org/affaire-auchan-rana-plaza-de-nouvelles-preuvesde-violations-des-droits-des-travailleurs-dans-les-usines-sous-traitantes-du-distributeur].

Sir G. Fitzmaurice, "The General Principles of International Law Considered from the Standpoint of the Rule of Law”, Recueil des Cours, vol.92, 1957.

Steven R. Ratner, "Corporations and Human Rights: A Theory of Legal Responsibility", Yale Law Journal, vol.111., 2001.

Stephen Tully, International Corporate Responsibility, Alphen Aan Den Rijn, Kluwer Law International, 2012. Theodore Lewitt, "The Dangers of Social Responsibility”, Harvard Business Review, September-October 1958.

William Bourdon, Yann Queinec, Réguler les entreprises transnationales. 46 propositions, Paris, Sherpa, Décembre 2010, p.13 [available at : https://www.asso-sherpa.org/ wp-content/uploads/2013/11/CDP-francais.pdf].

Woolf Committee, Committee Report on Business Ethics, Global Companies and the Defence Industry: Ethical Business Conduct in Bae Systems Plc — The Way Forward, May 2008.

Zachary Douglas, "The Plea of Illegality in Investment Treaty Arbitration”, ICSID Review, Vol. 29, No. 1, 2014.

Zygmunt Bauman, La cultura en el mundo de la modernidad líquida, Mexico, FCE, 2013. 
Para publicar na Revista de Direito Internacional, acesse o endereço eletrônico www.rdi.uniceub.br ou www.brazilianjournal.org.

Observe as normas de publicação, para facilitar e agilizar o trabalho de edição. 